\title{
Structural Means for Fire-Safe Wooden Façade Design
}

\author{
Thomas Engel (D* and Norman Werther (D), Department of Civil Geo and \\ Environmental Engineering, Chair of Timber Structures and Building \\ Construction, Technical University of Munich, Arcisstr. 21, 80333 Munich, \\ Germany
}

Received: 31 March 2021/Accepted: 25 August 2021/Published online: 22 October 2021

\begin{abstract}
This study investigates five fire stop variants used to limit the spread of fire on wooden façades. For this purpose, five fire tests using various types of wooden façade claddings and different fire stops were conducted as full-scale tests and compared to the existing findings. The influences and interactions between the material qualities of the external wall behind the façade cladding, the construction type of the wooden façade cladding, the design of the substructure, the depth of the ventilation gap, and the design of the fire stops were investigated. In evaluating the fire stops, the design of the interior corners, the joint design, and the influence of thermal expansion were examined. Finally, design proposals for the design of fire stops at wooden façades in order to limit the spread of fire were derived based on this evaluation. The outlook presents further needs that need to be investigated in the future in order to clarify undiscussed aspects or points that were ultimately not evaluated within the scope of this study.
\end{abstract}

\section{Graphical Abstract}
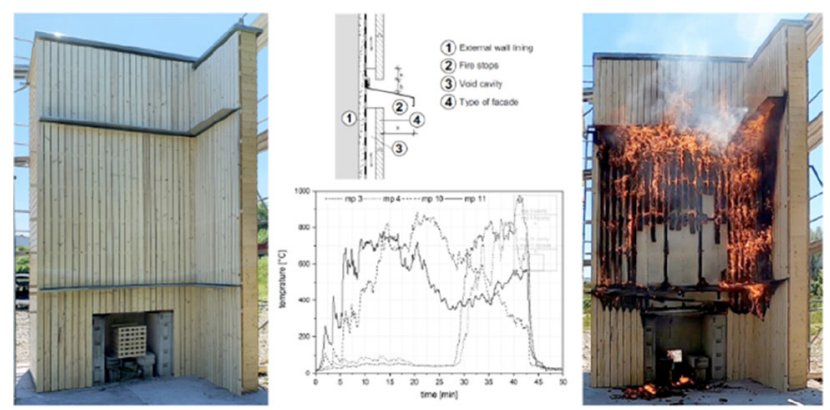

Keywords: Fire safety, Wooden façade, Façades, Fire spread, Fire stop, Spread of fire

\footnotetext{
*Correspondence should be addressed to: Thomas Engel, E-mail: engel@tum.de
} 


\section{Introduction}

The planning and execution of aesthetic façade constructions has always been an essential aspect of good architectural design. As a result, the building envelope is the first thing that catches the eyes of the viewers, i.e., the face of a building.

Wood material can be used to create aesthetic façades. Therefore, there is a great demand for feasible and safe wooden façades, even on tall buildings. Furthermore, timber is the world's leading renewable building material and is one of the key materials for the development of sustainable construction solutions. In the construction industry, timber can make a significant contribution to both the necessary decarbonization and the targeted use of renewable raw materials [1, 2].

However, concerns about the use of wood as a building material relate to the fact that wood is a combustible material. The potentially uncontrolled spread of fire through the façade is one of the key risks in the event of a fire. Ignoring the existing fire design principles usually results in fire incidents with an enormous degree of damage, regardless of the building material. Examples include the Grenfell Tower fire in UK [3] or, most recently, the fire in Ulsan, South Korea [4].

\section{Basics of Design}

\subsection{Differentiation Between Façade and External Wall}

This article describes structural measures used for fire-safe wooden façades. In this context, the façade refers to the building envelope. This does not include the exterior wall, which separates the interior space of a building from the surroundings. Figure 1 represents the façade and substructure and the actual external wall (gray).

\subsection{Types of Wooden Facades}

Wooden façades can be used in various constructive designs, as shown in Fig. 1.

In most cases, wooden façades are designed as rear-ventilated façades by virtue of the requirements for weather and moisture protection [5]. This constructive design helps to remove moisture that has penetrated from the outside and condensation that has formed, which ensures durability [6, 7]. Regarding ventilated façades, a distinction is made between fully rear-ventilated façade claddings (open at the top and bottom) and merely partially rear-ventilated façade claddings, as shown in Fig. 1. Non-rear-ventilated wooden façade claddings are less common because of the aforementioned durability aspects.

However, rear-ventilated façade claddings represent the most critical case with respect to the fire safety of wooden façades. In comparison to non-combustible ventilated façades [8], the existence of a rear-ventilated void cavity and the presence of wood as combustible material can greatly increase the propagation of fire within the ventilated cavity [9-11]. Therefore, the focus of this study is on the fire safety of wooden claddings in rear-ventilated façade systems.

Another important influencing factor is the various types of cladding used in rear-ventilated wooden façades. Table 6 shows the common types of cladding typ- 


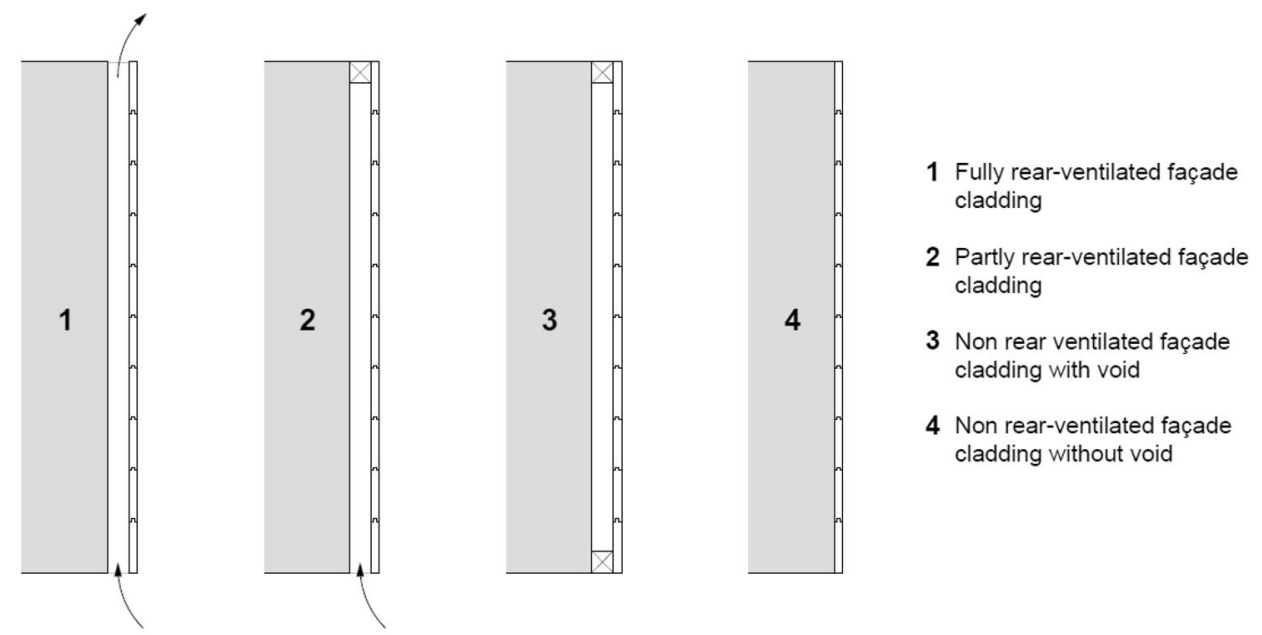

\section{Figure 1. Overview of structural designs of wooden façades.}

ically used in practice. The types shown in Table 6 range from closed façades (closed façade surface, e.g., wood-based panels) to open designed façades (no closed façade surface, e.g., open cladding). Figures 23 and 24 of the appendix show actual examples.

\subsection{Basics Regarding the Spread of Fire on Wooden Facades}

Fully rear-ventilated, partially rear-ventilated, and non-ventilated wooden façades have been used for some time, even on taller buildings. In this case, special constructive fire protection measures must be taken in order to prevent or limit the contribution of the façade cladding to fire spreading from story to story. Within this context, ventilated wooden façades in particular represent the most critical design case. Studies that directly compared non-ventilated and ventilated wooden façades concluded that wooden claddings with rear-ventilated cavities released almost twice as much energy as wooden façade claddings without rear-ventilated cavities, thus resulting in more severe flame formation and accelerated fire spread $[9,11,12]$.

Numerous research projects have identified fire stops as essential design measures in limiting the spread of fire on wooden façades to an acceptable level [1320].

Hietaniemi et al. [11] have summarized the results of several studies. When there are fire stops in the rear-ventilated cavity, the fire propagation speed is halved to about $20 \mathrm{~cm} / \mathrm{min}$ from the speed of $40 \mathrm{~cm} / \mathrm{min}$, which corresponds to an open fully rear-ventilated cavity $[11,12]$.

The spread of fire on wooden façades can be effectively limited by means of horizontal fire stops (projections) which break the continuous wooden cladding and ventilation cavity in separate areas. Typically, horizontal fire stops (usually made of steel sheet, wood, or mineral building materials - as shown in Fig. 2) are 
(3)

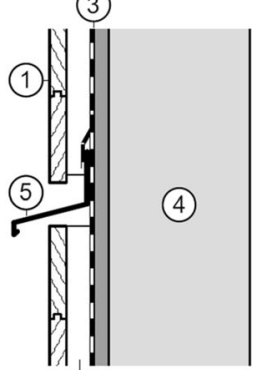

(2)

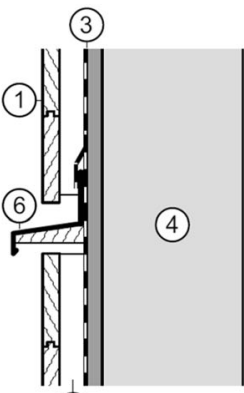

(2)

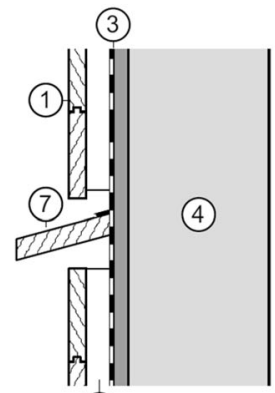

(2)
(1) Facade cladding

(2) Void cavity

(3) Foil

(4) External wall

(5) Steel sheet fire stop

(6) Steel sheet fire stop with wooden substructure

(7) Wooden fire stop

\section{Figure 2. Schematic illustration of typical horizontal fire stops (projections).}

executed on each story at the level of the floor slabs and over the entire façade. The dimensions and design of the horizontal projection in front of the façade cladding primarily depend on the type of façade cladding used (as shown in Table 6) $[13,14]$.

The spread of fire in interior corners of wooden façades should be limited by special measures, such as horizontal fire stops with a larger horizontal projection in front of the façade cladding, or by using non-combustible façade claddings in the area of the interior corners $[13,14]$.

Another alternative for preventing the spread of fire at the façade is to use projecting non-combustible panels or slabs above openings. These projections deflect the fire plume away from the façade [21-24]. This solution is often used in highrise buildings [25] but restricts the architectural design options for the façade.

\subsection{Analysis Existing Experimental Investigations}

The fire safety of wooden façades was investigated by the Swiss Lignum research group as part of an experimental campaign in the early 2000s.

33 façade fire tests using various wooden façade claddings and different structural fire protection measures were conducted at MFPA in Leipzig, Germany, but the results were never fully published. The face of the test stand had a height of $8.3 \mathrm{~m}$ and a width of $3.3 \mathrm{~m}$ and was made of masonry. The influence of an interior corner was investigated via four tests. In the MFPA set-up, the main face of the test stand had a width of $2.4 \mathrm{~m}$ and the return wall (wing) had a width of $1.4 \mathrm{~m}$. The combustion chamber was located at the bottom of the main wing. A $50 \mathrm{~kg}$ wooden crib was used as the fire load in 27 of the tests, and a $25 \mathrm{~kg}$ wooden crib in two of the tests. The $25 \mathrm{~kg}$ wooden cribs were used in conjunction with a corner application of the walls.

In addition, six real-scale fire experiments were performed in a vacant building in Merkers, Germany which was lined with wooden façade claddings (about $700 \mathrm{~m}^{2}$ ). The experiments sought to validate the results of the aforementioned fire tests on an actual building using realistic fire loads [13]. An experiment with a fire source outside of the building in front the façade (100 kg wood crib), a balcony 


\section{Table 1 \\ Minimum Projection of Horizontal Fire Stops Depending on the Type of Cladding [1 5]}

\begin{tabular}{|c|c|c|c|c|}
\hline \multirow[b]{2}{*}{ Cladding type } & \multirow[b]{2}{*}{ Orientation } & \multirow[b]{2}{*}{$\begin{array}{l}\text { Depth of the venti- } \\
\text { lation cavity }\end{array}$} & \multicolumn{2}{|c|}{$\begin{array}{l}\text { Overhang/projection depth of the hori- } \\
\text { zontal fire stop }\end{array}$} \\
\hline & & & $\begin{array}{l}\text { Sheet steel or mineral- } \\
\text { bonded panels }\end{array}$ & $\begin{array}{l}\text { Wood or } \\
\text { wood-based } \\
\text { material }\end{array}$ \\
\hline Wood-based panels & $\begin{array}{l}\text { Horizontal or } \\
\text { vertical }\end{array}$ & $\leq 100 \mathrm{~mm}$ & $\begin{array}{l}\geq 10 \mathrm{~mm} \\
\text { without }^{\mathrm{b}}\end{array}$ & $\begin{array}{l}\geq 20 \mathrm{~mm} \\
\text { without }^{\mathrm{b}}\end{array}$ \\
\hline $\begin{array}{l}\text { Form-fit paneling } \\
\text { and cladding } \\
\text { Profile with tongue } \\
\text { and groove }\end{array}$ & $\begin{array}{l}\text { Horizontal or } \\
\text { vertical }\end{array}$ & $\leq 100 \mathrm{~mm}$ & $\begin{array}{l}\geq 10 \mathrm{~mm} \\
\text { without }^{\mathrm{b}}\end{array}$ & $\begin{array}{l}\geq 20 \mathrm{~mm} \\
\text { without }^{\mathrm{b}}\end{array}$ \\
\hline \multirow[t]{2}{*}{$\begin{array}{l}\text { Force-fit paneling } \\
\text { and cladding }\end{array}$} & Horizontal & $\begin{array}{l}\leq 50 \mathrm{~mm} \\
\leq 100 \mathrm{~mm}\end{array}$ & $\begin{array}{l}\geq 10 \mathrm{~mm} \\
\text { without } \\
\geq 50 \mathrm{~mm} \\
\geq 10 \mathrm{~mm}^{\mathrm{a}} \\
\text { without }^{\mathrm{b}}\end{array}$ & $\begin{array}{l}\geq 20 \mathrm{~mm} \\
\text { without }^{\mathrm{b}} \\
\geq 50 \mathrm{~mm} \\
\geq 20 \mathrm{~mm}^{\mathrm{a}} \\
\text { without }^{\mathrm{b}}\end{array}$ \\
\hline & Vertical & $\leq 100 \mathrm{~mm}$ & $\begin{array}{l}\geq 100 \mathrm{~mm} \\
\geq 50 \mathrm{~mm}^{\mathrm{a}} \\
\text { without }^{\mathrm{b}}\end{array}$ & $\begin{array}{l}\geq 100 \mathrm{~mm} \\
\geq 50 \mathrm{~mm}^{\mathrm{a}} \\
\text { without }^{\mathrm{b}}\end{array}$ \\
\hline $\begin{array}{l}\text { Open cladding } \\
\text { Strip cladding }\end{array}$ & Horizontal & $\leq 50 \mathrm{~mm}$ & $\begin{array}{l}\geq 50 \mathrm{~mm}^{\mathrm{a}} \\
\geq 100 \mathrm{~mm}^{\mathrm{c}}\end{array}$ & $\begin{array}{l}\geq 50 \mathrm{~mm}^{\mathrm{a}} \\
\geq 100 \mathrm{~mm}^{\mathrm{c}}\end{array}$ \\
\hline $\begin{array}{l}\text { Cover cladding } \\
\text { Inverting cladding } \\
\text { Cover strip cladding }\end{array}$ & Vertical & $\leq 100 \mathrm{~mm}$ & $\geq 200 \mathrm{~mm}$ & $\geq 200 \mathrm{~mm}$ \\
\hline
\end{tabular}

${ }^{a}$ Cladding of oak, sweet chestnut, robinia, elm

${ }^{\mathrm{b}}$ Only for partly ventilated (not fully ventilated)

${ }^{\mathrm{c}}$ Joint between boards $\leq 10 \mathrm{~mm}$, otherwise fire stop $\geq 200 \mathrm{~mm}$

fire experiment (150 kg wood crib), and four compartment fires with wooden cribs (fuel load density $600 \mathrm{MJ} / \mathrm{m}^{2}$ and $800 \mathrm{MJ} / \mathrm{m}^{2}$ respectively) were conducted.

These real-scale fire experiments confirmed that the various structural measures investigated in the 33 fire tests that effectively limit the spread of fire can also be applied to actual buildings. It was thus concluded that the overall findings from the façade tests could be transferred to real buildings for further application. It should be noted, however, that only fire stops made of steel sheet were used in the real-scale fire experiments.

Following evaluation and interpretation of the results, the structural fire safety measures were published in [13]. An overview of the findings is summarized in Table 1 for buildings of medium height ( $>11 \mathrm{~m} ; \leq 30 \mathrm{~m}$ total height).

Specific regulations are presented herein along with the full documentation for façades with window bands, façades with single balconies in timber construction, and for other construction types [13]. 


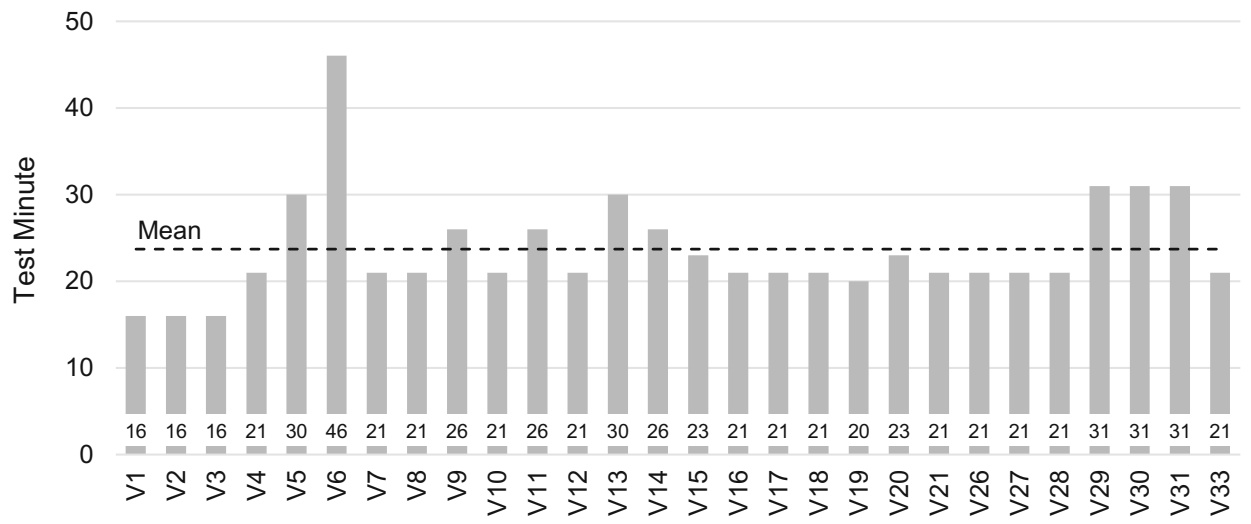

Facade fire test

\section{Figure 3. Diagram showing the test duration in minute at which the façade fire tests were extinguished.}

Design solutions for the interior corners of façades with wooden claddings are also presented in [13]. In these areas, the overhang of the horizontal fire stop is recommended to be at least twice the projection of the standard case, which is typically in the range of $150 \mathrm{~mm}-300 \mathrm{~mm}$.

The wooden façades investigated were extinguished after an average time of 24 min. The basis for this approach was the assumption in [26], in which it was interpreted that the fire service arrives on side after a period of $15 \mathrm{~min}$, so the spread of fire on the façade over a longer period need not be investigated. For this reason, the fire was always extinguished after 15 or $20 \mathrm{~min}$, but a longer exposure time was also considered in individual cases [13]. Figure 3 shows the relevant test durations after which the façades were extinguished; only fire tests on façades with wooden claddings are shown.

Based on the results of the Lignum fire tests, the fire behavior of wooden façades can be reliably assessed up to a fire duration of about $20 \mathrm{~min}$. No statements can be made about the behavior of wooden façades exposed to fire for longer durations. Therefore, further investigations were needed regarding whether the design measures developed in [13] can effectively limit the spread of fire in the event of longer fire exposures. A study of wooden façades in Sweden found that, in wooden façades with a rear-ventilated cavity, the spread of fire in the rear ventilation cavity increases sharply from $10 \mathrm{~min}$ onwards. This result supports the aforementioned concern [9].

Based on the Swiss results, an Austrian research team investigated five further wooden façade systems and fire stops on a façade test stand in accordance with ÖNORM B 3800-5 [16, 27]. In summary, the results reflected the following findings [14] (Table 2).

Five variations of a fire-safe design are presented for interior corners. Depending on the type of cladding and the distances to window openings, these show projections for horizontal fire stops of $100 \mathrm{~mm}-300 \mathrm{~mm}$ in the interior corner. 


\section{Table 2}

Dimensions of the Overhang/Projection for Fire Stops Depending on the Type of Cladding [1 4]

\begin{tabular}{|c|c|c|}
\hline Cladding type & Material fire stop & Overhang \\
\hline $\begin{array}{l}\text { All exterior wall cladding including open cladding (vertical and } \\
\text { horizontal) with the following conditions: } \\
\text { Board } \geq 20 \mathrm{~mm} \times 70 \mathrm{~mm} \\
\text { Joint } \leq 10 \mathrm{~mm}\end{array}$ & $\begin{array}{l}\text { Steel sheet } \\
\text { Timber with sheet } \\
\text { metal covering } \\
\text { Timber } \mathrm{d} \geq 40 \mathrm{~mm}\end{array}$ & $\geq 200 \mathrm{~mm}$ \\
\hline $\begin{array}{l}\text { Form-fit paneling and cladding, force-fit paneling and cladding, } \\
\text { wood-based panels }\end{array}$ & $\begin{array}{l}\text { Steel sheet } \\
\text { Timber with sheet } \\
\text { metal covering }\end{array}$ & $\geq 100 \mathrm{~mm}$ \\
\hline
\end{tabular}

\section{Table 3}

\section{Dimensions of the Overhang of Fire Stops According to the Type of Cladding and the Material of the External Wall Behind the Wooden Façade [19]}

\begin{tabular}{lllll}
\hline & & \multicolumn{3}{c}{ Overhang of the fire stop for } \\
\cline { 3 - 5 } Thickness & $\begin{array}{c}\text { Materiality of the lining behind the woo- } \\
\text { den façade (surface of the external wall) }\end{array}$ & $\begin{array}{c}\text { Panel with } \\
\text { closed joints }\end{array}$ & $\begin{array}{c}\text { Horizontal } \\
\text { wood clad- } \\
\text { ding }\end{array}$ & $\begin{array}{c}\text { Vertical } \\
\text { wood clad- } \\
\text { ding }\end{array}$ \\
\hline$\geq 26 \mathrm{~mm}^{\mathrm{a}}$ & $\begin{array}{l}\text { Non-combustible } \\
\text { Stone wool }\end{array}$ & $\geq 150 \mathrm{~mm}^{\mathrm{c}}$ & $\geq 150 \mathrm{~mm}^{\mathrm{c}}$ & $\geq 200 \mathrm{~mm}^{\mathrm{c}}$ \\
$18-$ & Non-combustible & $\geq 150 \mathrm{~mm}^{\mathrm{c}}$ & $\geq 150 \mathrm{~mm}^{\mathrm{c}}$ & $\geq 250 \mathrm{~mm}^{\mathrm{c}}$ \\
$22 \mathrm{~mm}^{\mathrm{a}}$ & Non-combustible & $\geq 200 \mathrm{~mm}^{\mathrm{b}}$ & - & - \\
$20-$ & & & $\geq 200 \mathrm{~mm}^{\mathrm{b}}$ & $\geq 200 \mathrm{~mm}^{\mathrm{b}}$ \\
$22 \mathrm{~mm}^{\mathrm{a}}$ & & & & \\
\hline
\end{tabular}

${ }^{\mathrm{a}}$ For untreated wood

${ }^{\mathrm{b}}$ Reinforced fire stop made of wood with sheet metal covering

${ }^{\mathrm{c}}$ Steel sheet or wood with sheet metal covering possible for fire stops

According to the Austrian design rules, it is permitted to omit fire stops between the penultimate story and the last story [14].

A French research team also investigated the behavior of wooden façades [1720] in the case of fire. The investigations in France were the basis for the French façade guide for wooden façades [19]. In comparative studies, it was shown that fire stops delay the temperature increase into the rear-ventilation cavity for almost $10 \mathrm{~min}$ [18]. The specifications from [19] are summarized below. The guideline requires mounting the fire stops to the structural wall with a fixation spacing of no greater than $500 \mathrm{~mm}$ (Table 3). 


\section{Large-Scale Fire Tests}

\subsection{Aim of the Study}

The aim of the testing was to investigate the spread of fire on wooden façades outside the primary fire plume of the window opening. Guidance on the design and choice of relevant fire stops was furthermore derived from the tests.

The burning of the wooden façade in the primary fire area is unavoidable and must therefore be accepted. The vertical spread of fire must nevertheless be limited. There should be no further uncontrolled fire spread outside of the flame from the primary fire.

Depending on the flame height, the flames can overrun several fire stops [28]. In typical room fires, as evidenced by studies of real fire incidents and fire tests, average flame heights of between $2.0 \mathrm{~m}$ and $4.5 \mathrm{~m}$ and flame peaks up to $6.0 \mathrm{~m}$ outside the opening can be expected. This depends on the fuel load, room geometry, ventilation conditions, opening geometry, and wind conditions [24, 29, 30]. The fire stop above the fire plume represents the relevant measure for limiting the spread of fire, as shown in Fig. 4.

Given that the burning of the wooden façade in the primary fire area is unavoidable, the size of the resulting flame from an internal fire (e.g., from a window opening in a compartment fire) or an external fire (e.g., from a fire that occurs outside of the building in front of the façade) played no role in this investigation. For both scenarios, the governing factor is the fire propagation along the wooden façade above the primary flame. The aim was to obtain approaches for evaluating the fire stop above the primary flame.

Crucial for the following investigation is the degree of effectiveness of the constructive fire stops and protection measures. Of importance are:

- Whether or not the fire stop can limit the vertical and horizontal spread of fire outside the area of the fire plume coming from the window opening

- Whether or not self-extinction at the façade occurs after the compartment fire is be extinguished

- Whether or not the spread of fire can be delayed by the fire safety measures.

The primary focus herein is on the vertical spread of fire, because the Swiss studies have already shown that the horizontal spread of fire occurs only to a very small extent at wooden façades [13].

\subsection{Test Set-up}

For reasons of repeatability and reproducibility, the tests were performed on a façade test stand based on German standard DIN 4102-20 [31]. This test method considers a fire exposure via a combustion chamber with a $30 \mathrm{~kg}$ wooden crib, as shown in Fig. 5. Although the thermal exposure of a $30 \mathrm{~kg}$ wooden crib is not entirely equivalent to that of a flame coming from a window opening in a fully developed compartment fire, a similar thermal exposure occurs at the façade in the area of the flame tip and above the lintel of the opening [28, 29]. For this rea- 


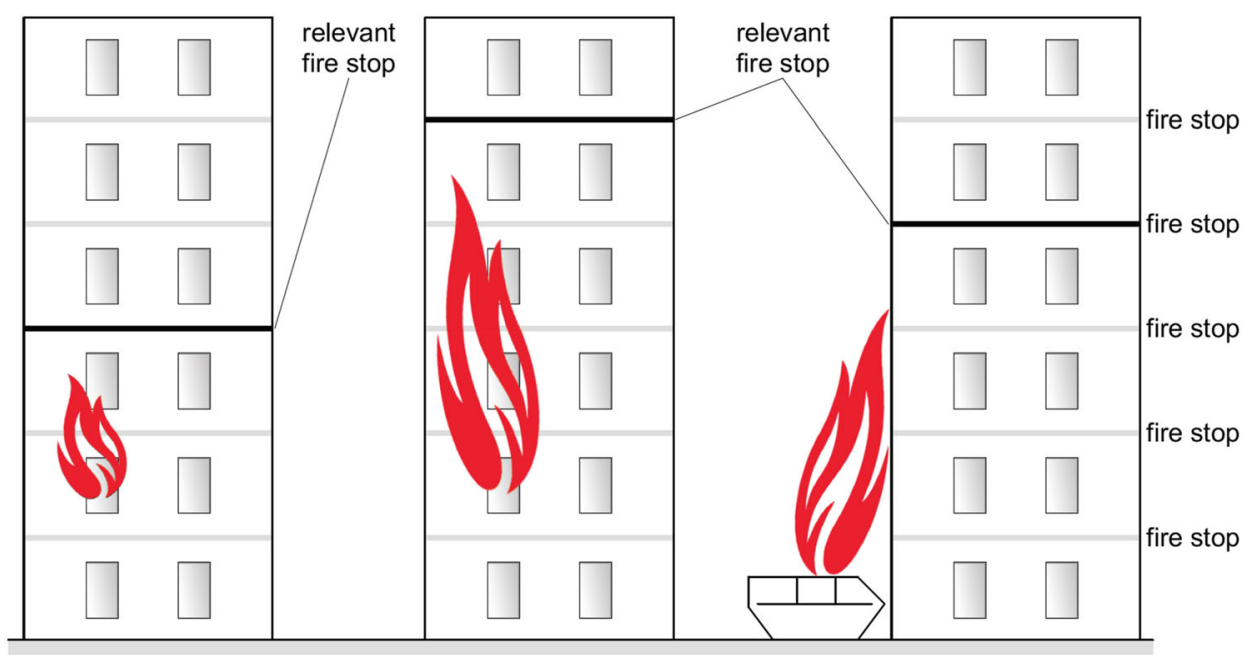

Figure 4. Various fire scenarious at the façade and representation of the relevant fire stop for a wooden façades.

son, the test method was suitable for investigating fire propagation outside the primary fire plume at the flame tip.

A two-layer lining of $18 \mathrm{~mm}$ gypsum boards type $\mathrm{F}$ was used as the exterior face of the test stand, and the respective façade claddings being tested were mounted upon it. The dimensions of the test stand and the position of the fire stops are shown in Fig. 5. To exclude an early failure of the fire stops, the fixation of any fire stop was anchored into the structural timber elements behind the gypsum lining [32].

As a fire load, $30( \pm 1.5) \mathrm{kg}$ of wooden cribs made of planed spruce timber with a density of $475( \pm 25) \mathrm{kg} / \mathrm{m}^{3}$ and a wood moisture content of $12.4 \%$ were arranged in the form of $40( \pm 2) \times 40( \pm 2) \times 500( \pm 10)$ mm sticks in staggered layers with a crosswise arrangement $\left(90^{\circ}\right)$ at a wood-to-air ratio of 1:1 in the combustion chamber. The base area of the wooden cribs was $500 \times 500 \mathrm{~mm}$.

The combustion chamber $(1.0 \mathrm{~m}$ wide and $0.8 \mathrm{~m}$ deep) was built from aerated concrete blocks, and a rectangular opening with dimensions $300 \times 250 \mathrm{~mm}$ $(\mathrm{w} \times \mathrm{h})$ corresponding to an area of $0.075 \mathrm{~m}^{2}$ was arranged at the backside for a mechanical ventilation of the crib, as shown in Fig. 5.

Due to the standardized test set-up, only façade fires spreading over one and a half stories can be investigated. It is known from studies on parallel room fires over two superimposed stories that the plume and the flame height increase [33, 34]. The same phenomenon can be expected in the case of a façade fire over several stories. In view of the unpublished test reports from Switzerland, it can be seen that, in the case of a fire spreading over the fire stops, parts of the wooden facade of the story below are already burned down. This leads to the conclusion that the test method was adequate for a basic investigation. 


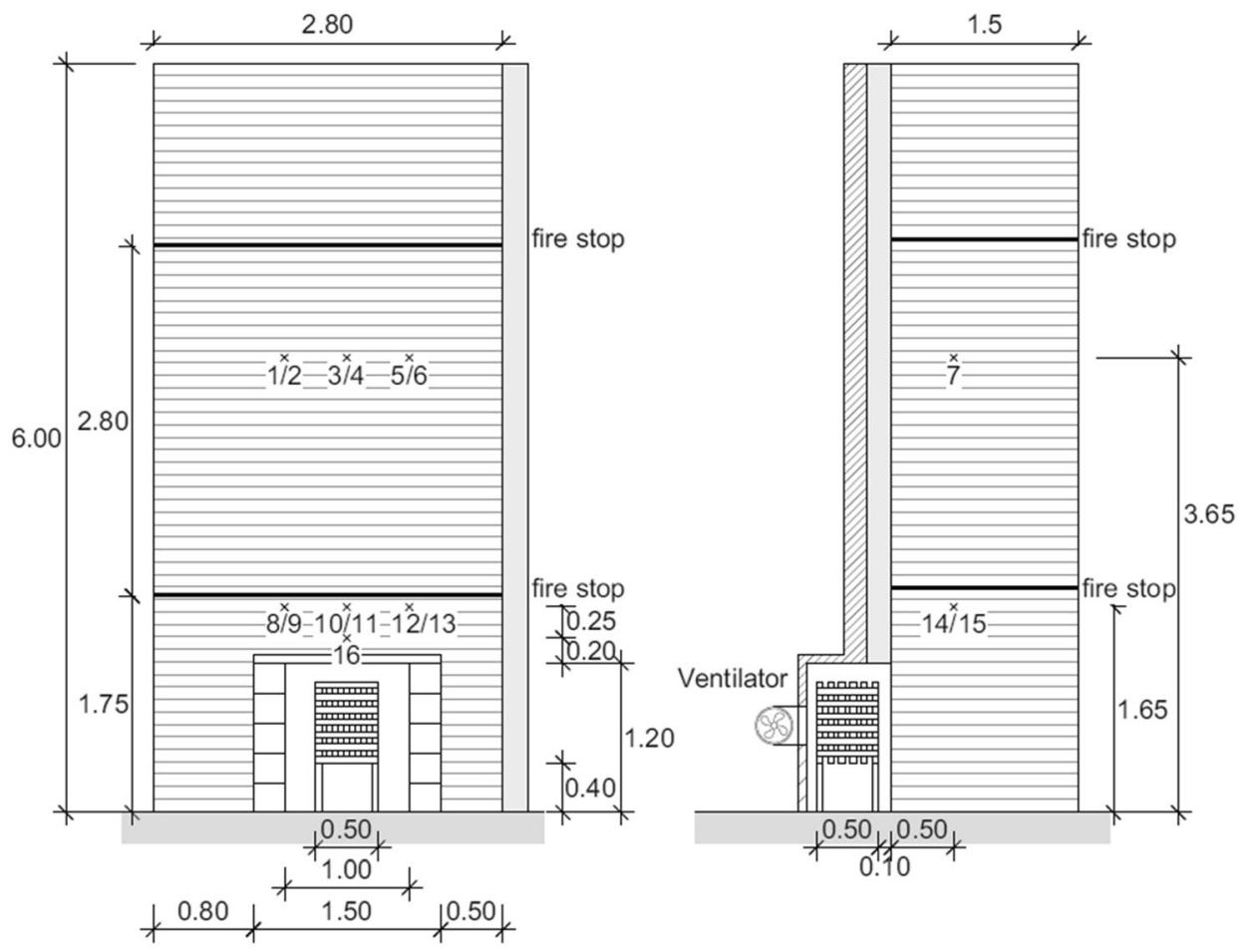

\begin{tabular}{ll}
\hline Measuring Points & Location \\
\hline $1,3,5,8,10,12,14$ & Centered in the ventilation cavity \\
\hline $2,4,6,7,9,11,13,15,16$ & $20 \mathrm{~mm}$ in front of the facade cladding
\end{tabular}

\section{Figure 5. Façade test stand with dimensions and measuring points; unit of dimensions [m].}

\subsection{Measurements}

16 sheathed thermocouples of type K according to EN 60584-1 [35] with an outer diameter of $3 \mathrm{~mm}$ were arranged on the test rig for temperature measurement, as shown in Fig. 5. The thermocouples were guided through a hole from the rear of the test stand onto the façade and fixed either in the rear ventilation cavity or on the surface of the façade by means of wire. They were positioned centrally in the rear-ventilated void cavity or at a distance of $20 \mathrm{~mm}$ from the façade cladding [32]. Figures 5 and 6 show the positions of the thermocouples.

All sheathed thermocouples were orientated horizontally along the façade at $\geq 130 \mathrm{~mm}$ parallel to the isotherm in order to enable a correct temperature measurement.

In addition, all tests were recorded using a video camera and thermal imaging camera. 


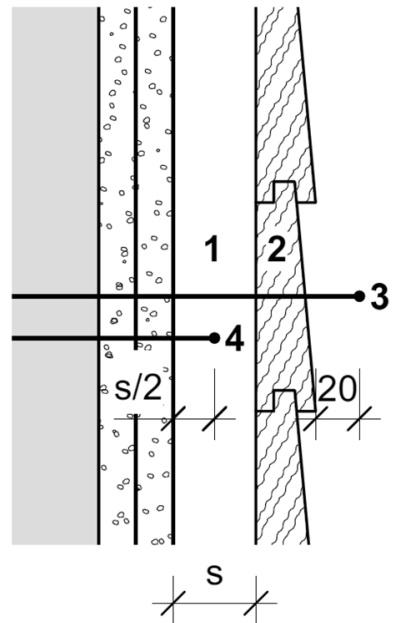

1 Ventilation cavity

2 External wall claddings

3 Thermocouple outside

4 Thermocouple ventilation cavity

\section{Figure 6. Description of the femperature measuring points [in $\mathrm{mm}$ ].}

\subsection{Specimen}

The individual experimental set-ups are shown in Table 4.

\subsection{Test Procedure}

The tests were performed on a wind-protected outdoor test stand. The corresponding weather data are provided in Table 7 of the appendix.

An overpressure ventilation in the combustion chamber was enabled by a fan located at the rear side and started $120 \mathrm{~s}$ after ignition.

The flame spread over the individual fire stops was reported with an indication of the time based on the observations and measurements. The tests were stopped when the second fire stop was exceeded or the flames reached the upper end of the test stand.

\section{Results}

Table 5 shows, for each test, the point in time at which: (i) the flame coming from the combustion chamber evenly impinged the façade, (ii) the first fire stop or the second fire stop was exceeded, and (iii) the test was stopped and the fire extinguished. In addition, the test observations with regard to any horizontal fire spread and self-extinction of the façade cladding are presented in Table 5. The observations from each test are briefly summarized in the following. Also shown are the temperature-time curve of measuring points $3,4,10$, and 11 , which were located in the centerline directly above the combustion chamber according to Fig. 5 in addition to at least one image of the respective façade immediately before extinguishing (end of test). 


$$
\text { HE }
$$




$$
\text { 桐 }
$$



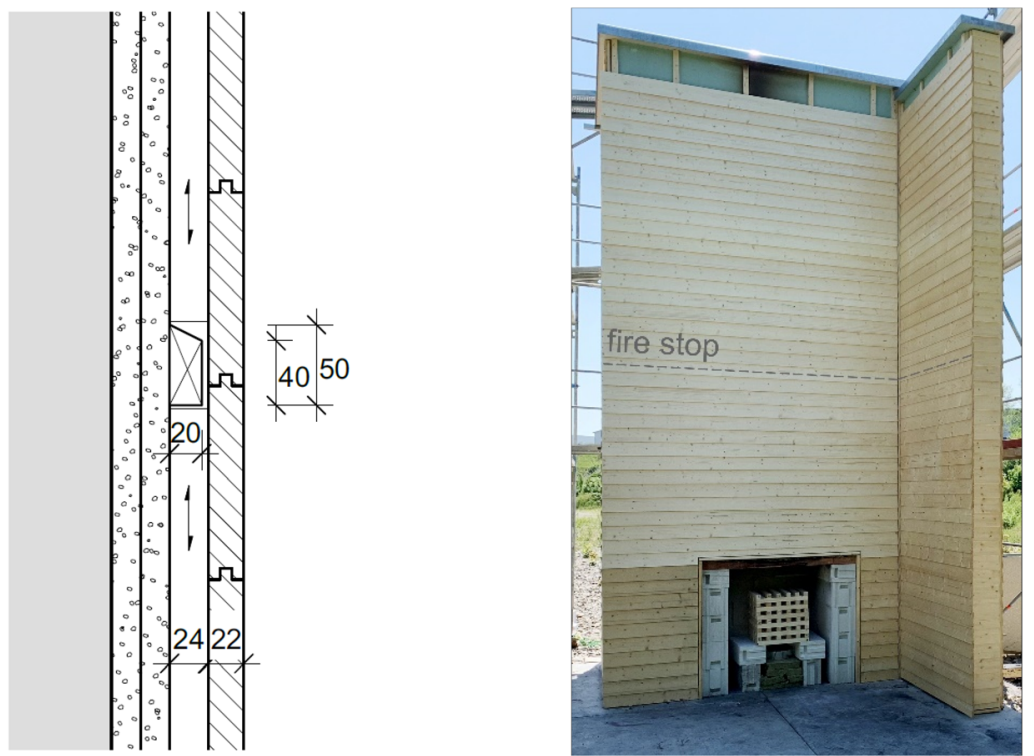

Figure 7. Vertical section and photo of the facade structure with visualized fire stop in Test 1 [in $\mathrm{mm}$ ].
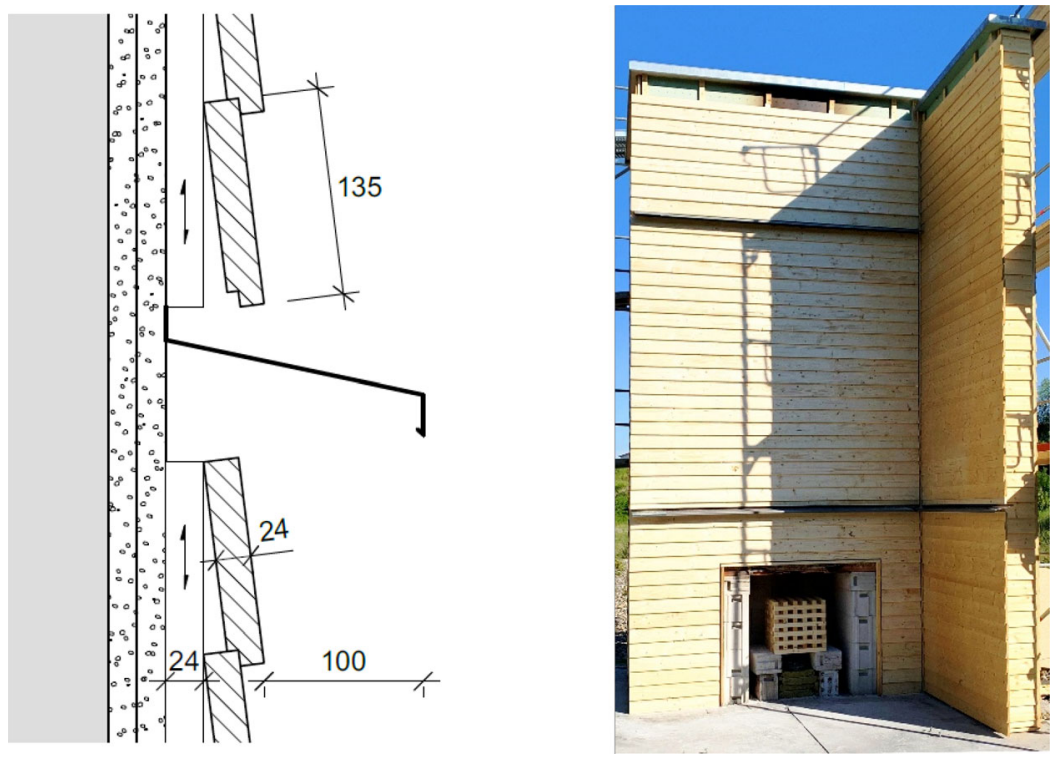

Figure 8. Vertical section and photo of the façade structure in Test 2 [in mm]. 

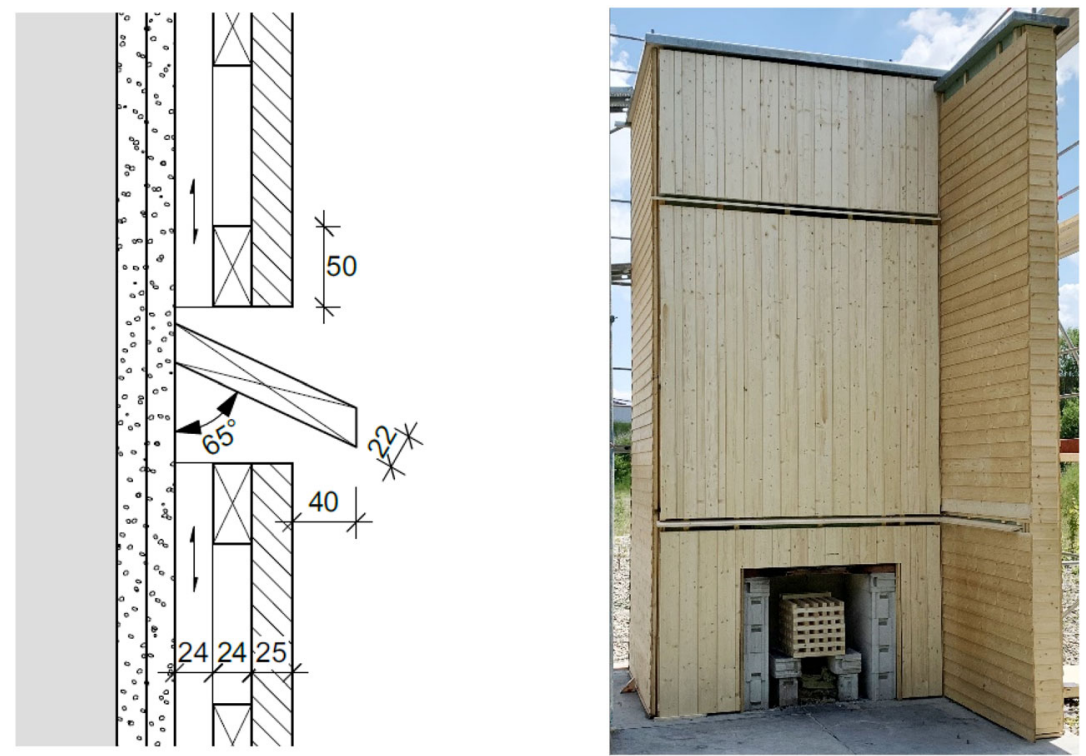

Figure 9. Vertical section and photo of the façade structure in Test 3 [in mm].
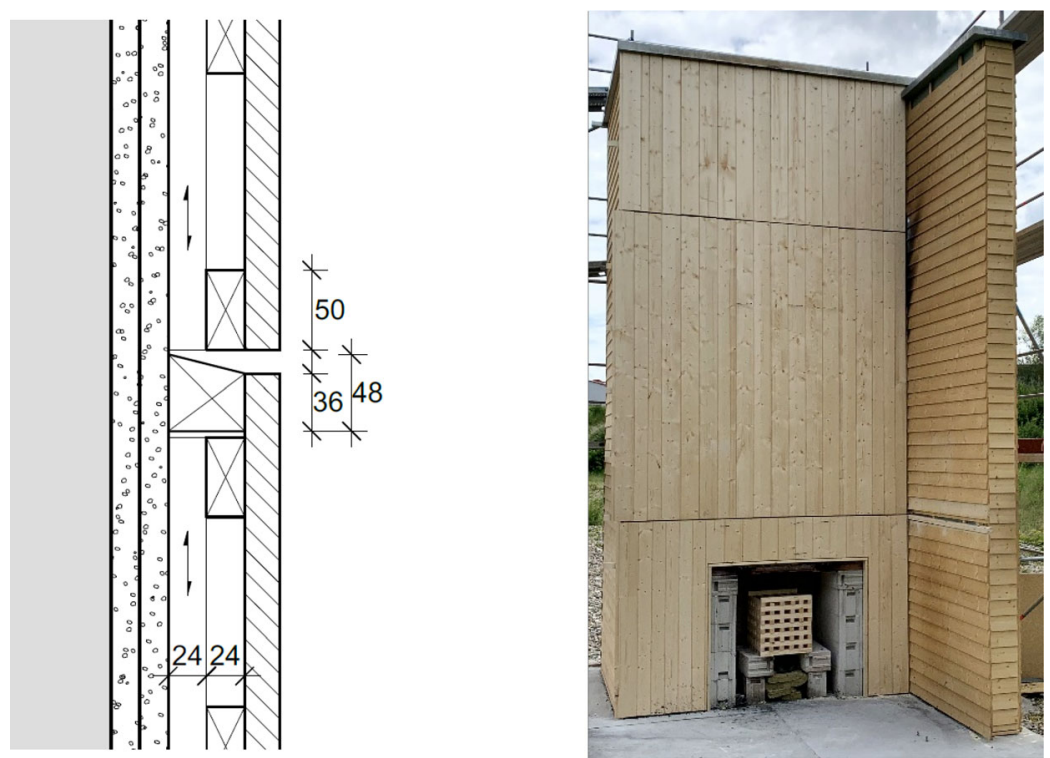

Figure 10. Vertical section and photo of the façade structure in Test 4 [in mm]. 

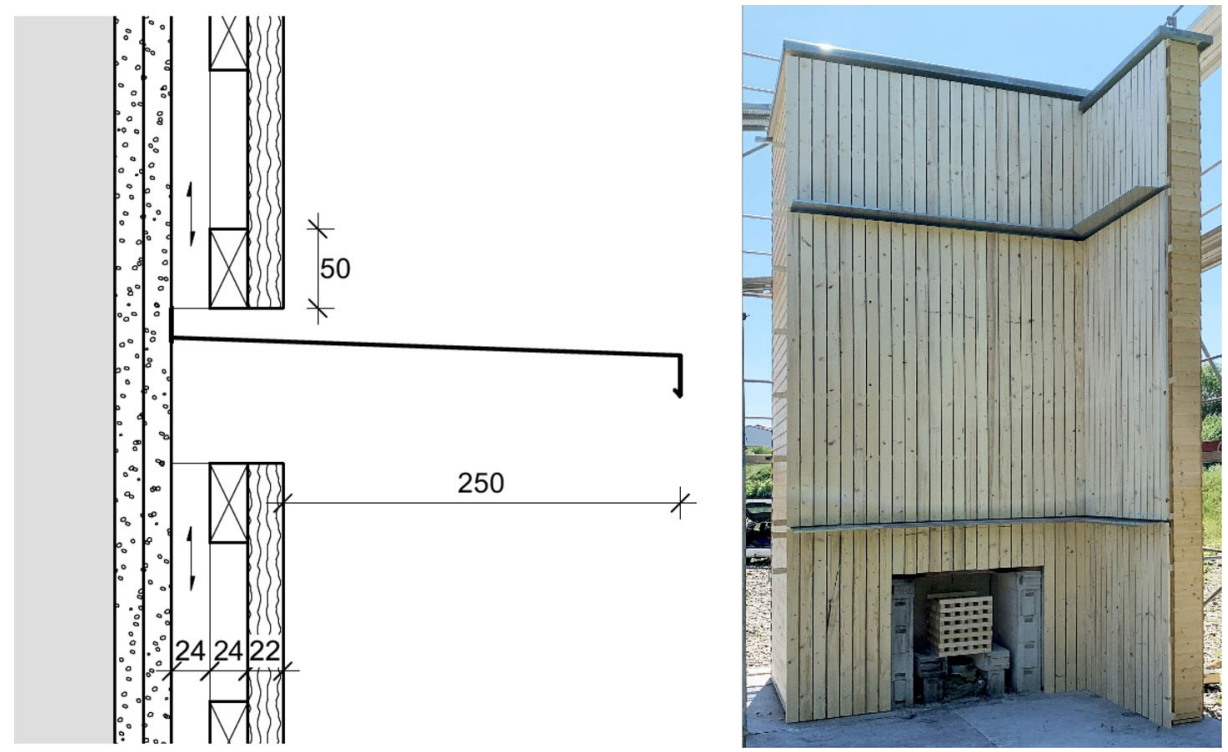

Figure 11. Vertical section and photo of the façade structure in Test 5 [in mm].

\subsection{Test 1}

As per Sect. 3.4, only one fire stop at a height of $3 \mathrm{~m}$ from the lower edge of the test stand was installed. This fire stop was exceeded after 40:00 min and the test ended after 47:00 min. No horizontal fire spread was observed during the test, as shown in Fig. 12. A self-extinction did not occur.

\subsection{Test 2}

The first charring above the first fire stop resulting from the flames coming from the combustion chamber was detected after 02:00 $\mathrm{min}$, but the façade above the first fire stop did not exhibit flaming combustion. The test was stopped after 46:30 min; self-extinction occurred. A horizontal spread of fire and charring of the façade cladding was only detected below the first fire stop due to the horizontal deflection of the flames, as shown in Fig. 13.

\subsection{Test 3}

After 01:40 min in Test 3, it was apparent that the first fire stop (overhanging wooden board) could no longer exclude a burning of the wooden cladding above the fire stop for the flame coming from the combustion chamber. Burning above the second fire stop was observed after 27:30 min. The test was terminated after 30:00 min because the flames reached the upper edge of the test stand. No self-ex- 


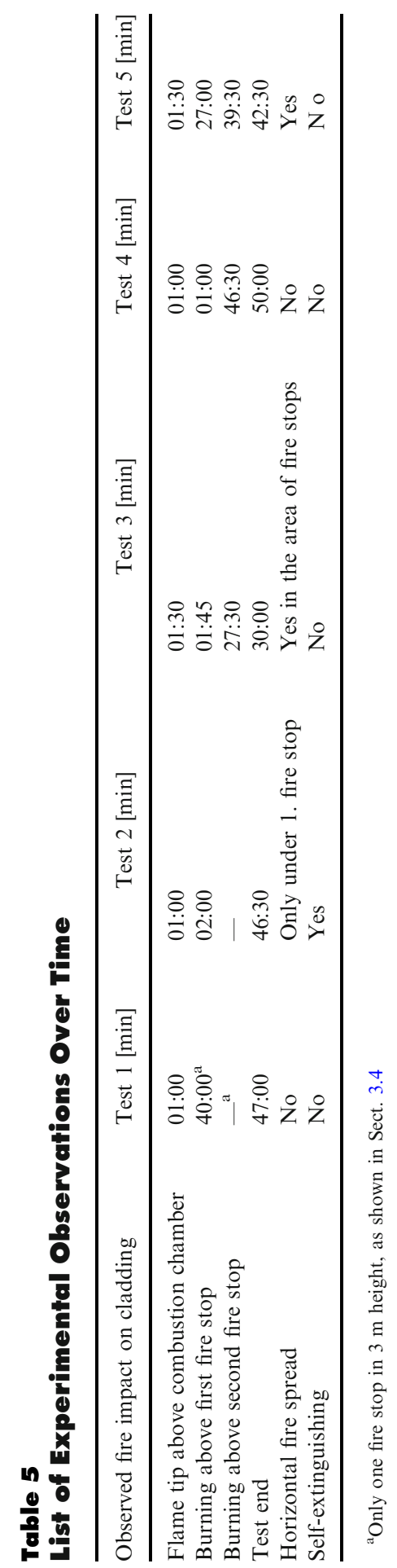



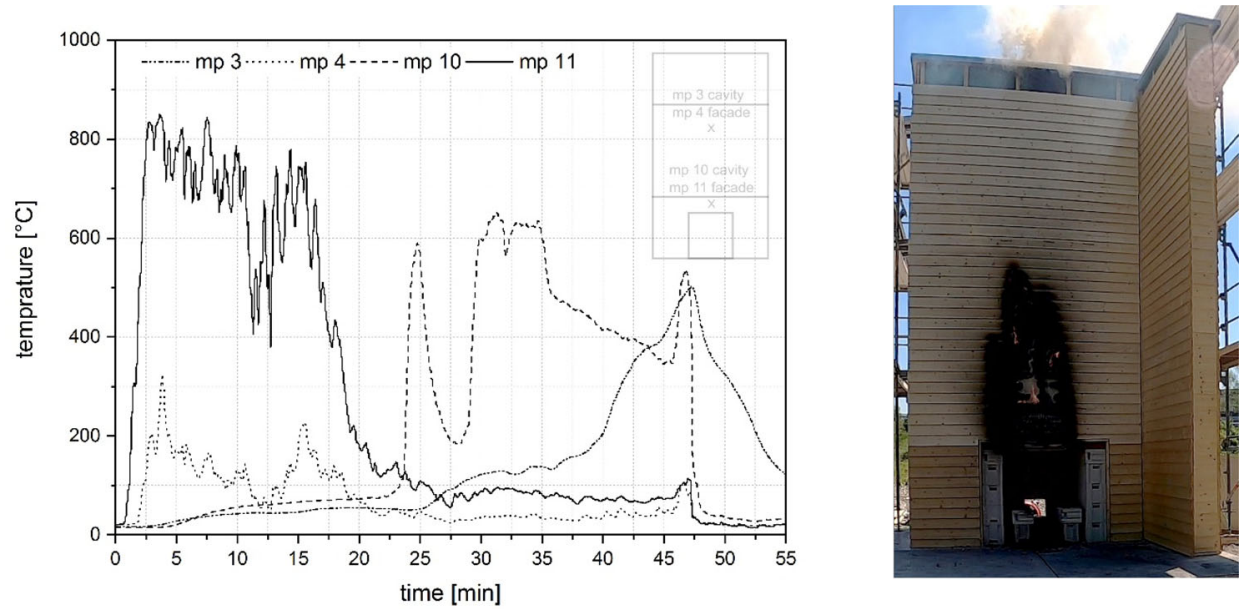

Figure 12. Temperature-time diagram for measuring points [mp] 3, 4, 10 , and 11 and a photo of Test 1 at minute 47.
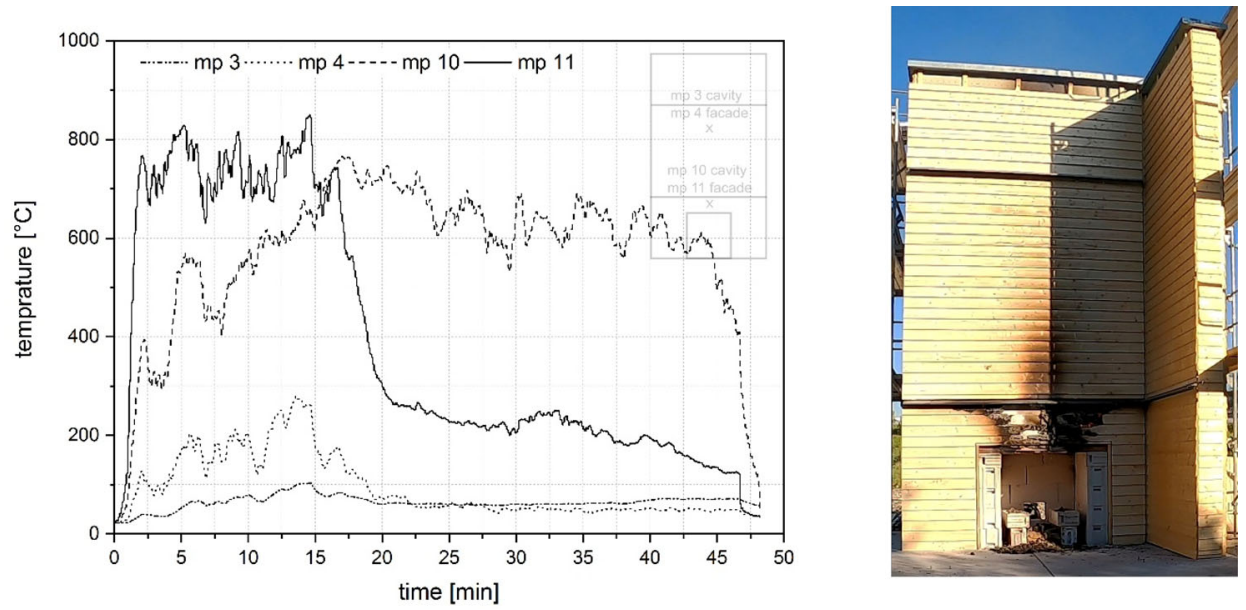

Figure 13. Temperature-time diagram for measuring points [mp] 3, 4, 10 , and 11 and a photo of Test 2 at minute 46.

tinction occurred. An obvious horizontal fire spread was observed directly in the area of each of the wooden fire stops, as shown in Fig. 14.

\subsection{Test 4}

In Test 4, with a closed rear-ventilated cavity at the top end of each story, the first fire stop exhibited no protection ability after only 01:00 $\mathrm{min}$, and the second fire stop was no longer able to prevent burning of the wooden cladding above the 

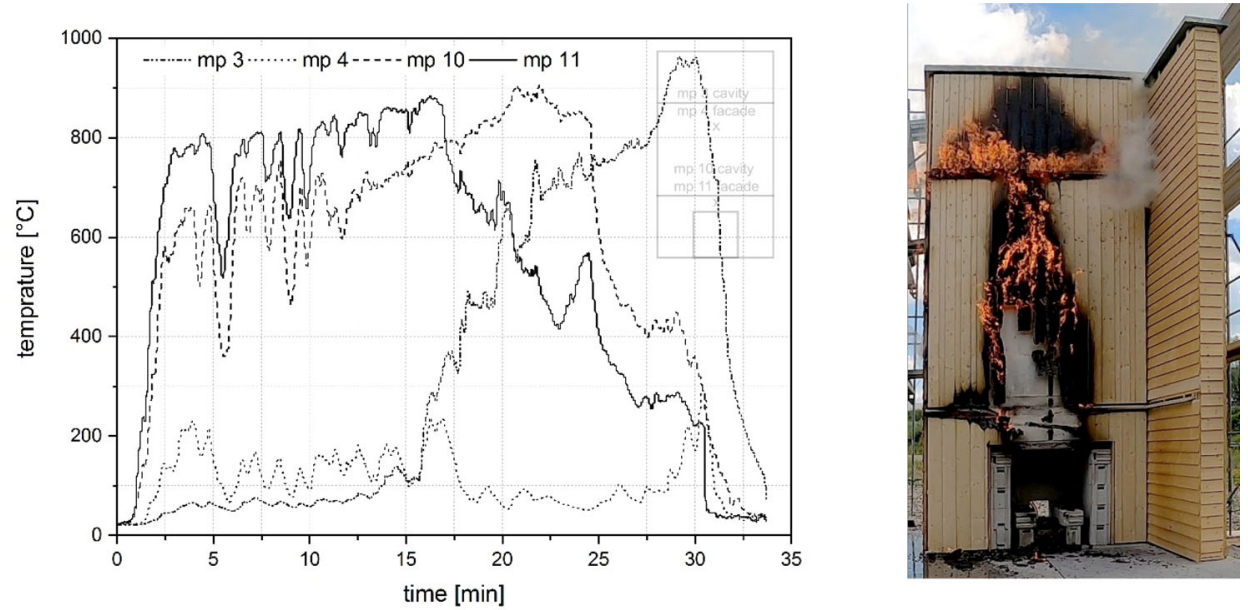

Figure 14. Temperature-time diagram for measuring points [mp] 3, 4, 10 , and 11 and a photo of Test 3 at minute 30.
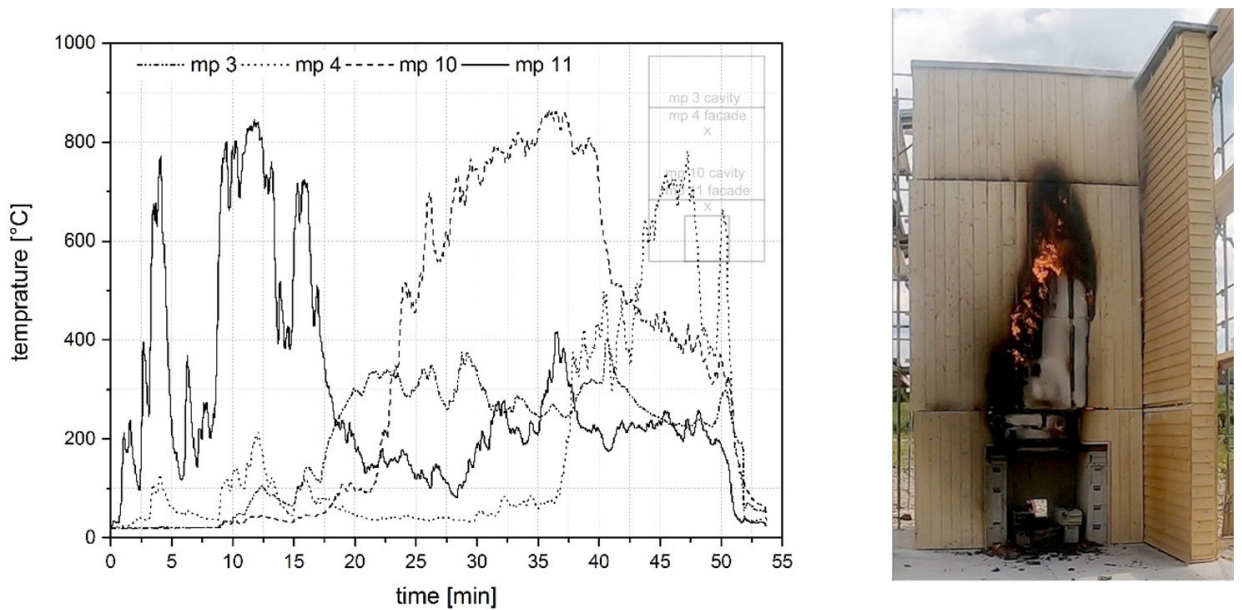

Figure 15. Temperature-time diagram for measuring points [mp] 3, 4, 10 , and 11 and a photo of Test 4 at minute 50.

fire stop after 46:30 min. The test was stopped after 50:00 min. Self-extinction did not occur. No horizontal spread of fire was detected, as shown in Fig. 15.

\subsection{Test 5}

The large overhang of the steel sheet fire stop in Test 5 prevented the spread of fire above the first fire stop for up to 27:00 min, as shown in Fig. 26 of the appendix. The fire spread above the first fire stop was caused by a gap between the steel sheet fire stop and the wall, through which hot gases rose, and by a deformation/ 

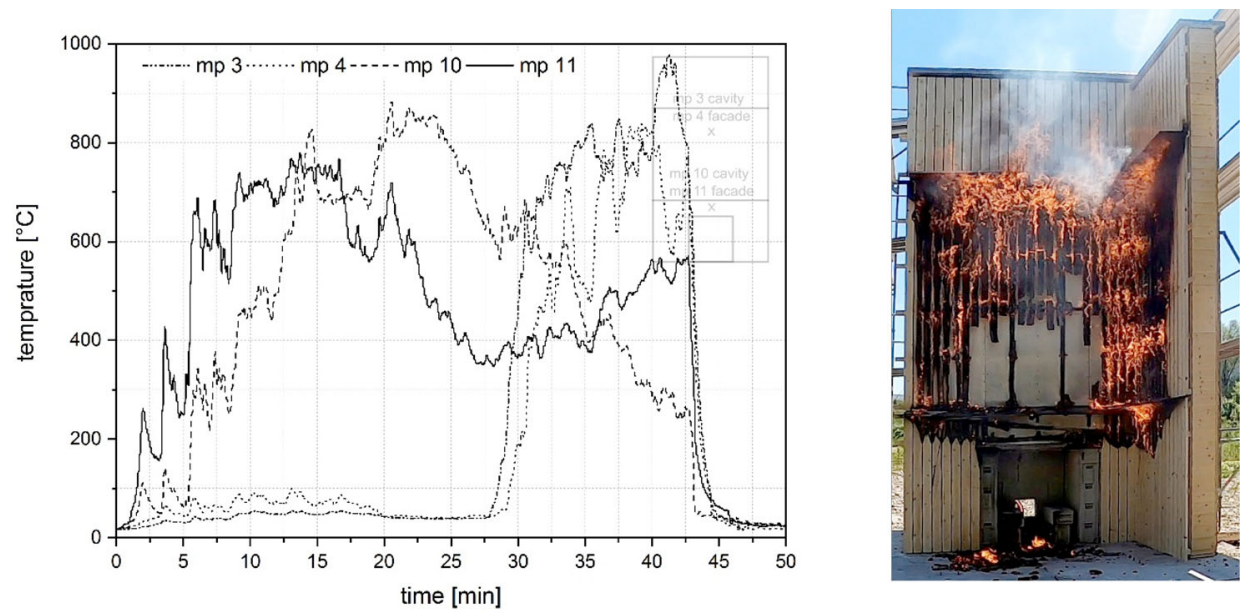

\section{Figure 16. Temperature-time diagram for measuring points [mp] 3, 4, 10, and 11 and a photo of Test 5 at minute 42.}

lifting of the steel sheet fire stop in the direction of the wooden façade. Due to the massive burning of the façade cladding, the second fire stop was first spilled by the fire in the corner area after 39:30 min. The test was stopped after 42:30 min. Self-extinction did not occur. Horizontal fire spread was observed in the entire façade area above the first fire stop, as shown in Fig. 16.

\section{Fire Design Measures for Wooden Façades}

\subsection{General}

The aim of this study was to define constructive measures that can prevent or limit the spread of fire on the wooden façade outside the primary flame area without any premature intervention by fire services. Furthermore, measures which able to lead to a self-extinction in consideration of the investigated scenarios were also to be identified.

The design measures described in the following sections can be derived in consideration of the experimental investigations in Sect. 2 and the test conducted in Sect. 3.

Figure 17 shows the typical structure of a ventilated wooden façade. Following the numbering shown in Fig. 17, the respective design principles for these components are described below.

\subsection{External Wall Lining Behind the Wooden Facade (No. 1)}

The outer surface of the external wall (No. 1 in Fig. 17) should be made of noncombustible building materials. The major influence of the combustibility of the outer face of the wall forming the inner boundary of the ventilation cavity was already confirmed in the French investigations [18]. The rear-ventilated void cavity 


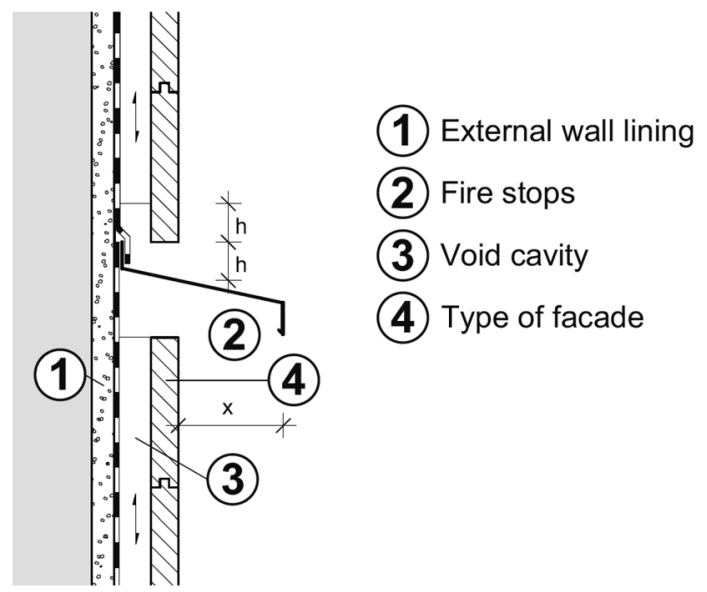

\section{Figure 17. Typical structure of a ventilated wooden façade.}

is formed by the wooden façade on one side and by the outer surface of the exterior wall on the other. If both surfaces are made of combustible materials, the fire spread will spread much faster within the void cavity and thus reach greater heights more quickly. A direct comparison of the previously described Test 1 and an unpublished industrial test [41] with a similar set-up but using wood fiberboard as the outer surface of the exterior wall also clearly shows this significant influence, as shown in Fig. 18. It should be noted that the measuring point for the variant with wood fiberboard was located $650 \mathrm{~mm}$ higher. Much higher tempera-

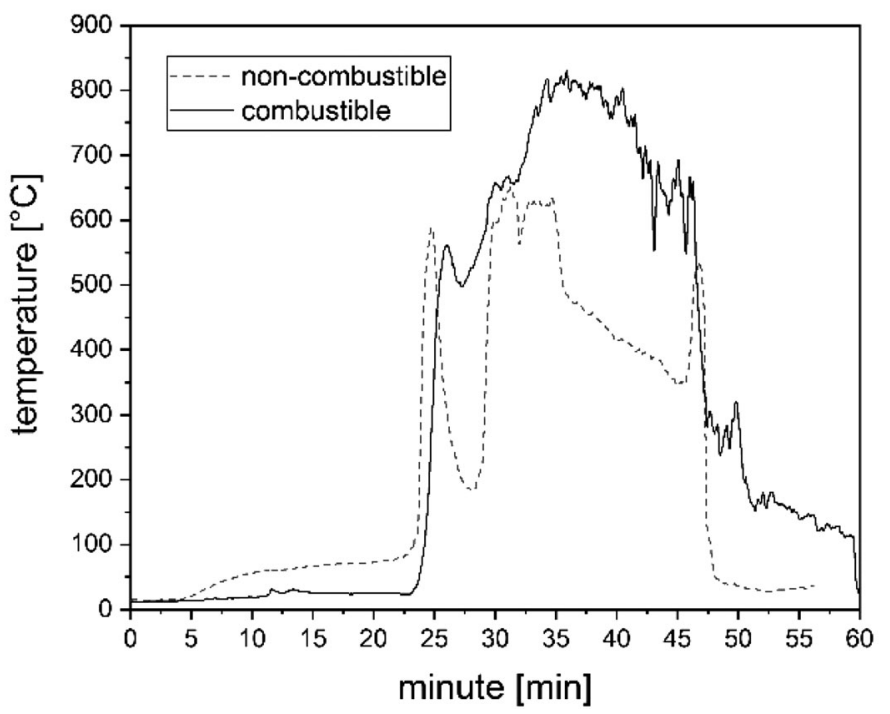

Figure 18. Temperature-time curve measured in the rear-ventilated cavity for combustible and a non-combustible linings of the outer wall behind the façade cladding. 
tures occurred even though the measuring point for the variant with wood fiberboard was farther away from the combustion chamber.

No further fire stops were arranged during the test with the wood fiberboard, so the test had to be stopped after only $31 \mathrm{~min}$, after which the flames had reached the upper end of the test stand.

For light timber frame or mass timber structures, it is recommended to use a layer of $2 \times 12.5 \mathrm{~mm}$ or $1 \times 18 \mathrm{~mm}$ gypsum plasterboard type $\mathrm{F}$ or gypsum fiberboard as the outer face of the external wall elements. Beyond the positive influence on the façade, such layers also provide $30 \mathrm{~min}$ of encapsulation for the wall elements behind [42].

The typical foils or membranes less than $0.5 \mathrm{~mm}$ thick that are required for weather protection or moisture control on top of the outer gypsum layer (as shown in Fig. 17) have no negative impact on the aforementioned behavior and, due to the low total heat of combustion, they make no noteworthy contribution to the spread of fire inside the ventilation cavity.

\subsection{Type of Facade (No. 4) and Ventilation Void Cavity (No. 3)}

In view of the available test reports listed in Sect. 2.4 and the findings obtained in our own investigation, it can be concluded that the fire behavior of a wooden façade is strongly dependent on the type of cladding and its application. This means that the type of façade in combination with the design of the substructure and ventilation cavity has a great influence on the spread of fire along the façade and, therefore, on the performance of fire stops.

In general, it was seen that a closed façade cladding design and reducing the depth of the rear-ventilation cavity resulted in improved façade performance with regard to fire spread. It can thus be stated that the types of façade claddings listed in Table 6-from top to bottom-should be assessed more critically from a fire safety point of view. This ranking also applies to the horizontal spread of fire. Looking at Table 5, it can be stated that a horizontal fire spread outside the fire stops was only observed for open façade claddings.

A panel cladding designed as a completely closed system represents the best design with regard to vertical and horizontal fire spread, and a vertical open cladding with four-sided fire exposure at the cladding thus represents the worst variant.

The spread of fire on open claddings exposed to fire on four sides is well illustrated by the experiments regarding vertical and horizontal fire propagation in [43]. The horizontal fire spread increased significantly at a smaller spacing. However, the vertical fire spread was significantly greater than the horizontal in all of the investigational set-ups.

The decisive factor with respect to the spread of fire is the degree of the thermal induced formation of gaps for the façade cladding. In all of the tests conducted, faster fire spread was observed after the first gaps appeared in the cladding towards the rear-ventilation cavity in the area of the primary flame, because the cladding was exposed to fire on two sides and sufficient oxygen was available. Regarding to the overall fire behavior, form-fit claddings with, e.g., tongue-andgroove joints which prevent continuous gaps for a longer fire duration typically behave better than force-fit claddings, especially when thermal deformation and 


\section{Table 6}

Overhang $\times$ Depending on the Various Types of Cladding for Wooden Façades

\begin{tabular}{|c|c|c|c|c|}
\hline Cladding type & Scheme & Orientation & $\begin{array}{c}\text { Overhang } \\
\times\end{array}$ & $\begin{array}{c}\text { Overhang } \times \text { in interior } \\
\text { corner }\end{array}$ \\
\hline \multicolumn{5}{|l|}{ Closed façades } \\
\hline Wood-based panels & & $\begin{array}{l}\text { Horizontal or } \\
\text { vertical }\end{array}$ & $\geq 50 \mathrm{~mm}$ & $\geq 150 \mathrm{~mm}$ \\
\hline $\begin{array}{l}\text { Form-fit paneling and } \\
\text { cladding }\end{array}$ & 4. & Horizontal & $\geq 50 \mathrm{~mm}$ & $\geq 150 \mathrm{~mm}$ \\
\hline \multirow[t]{2}{*}{$\begin{array}{l}\text { Profile with tongue and } \\
\text { groove }\end{array}$} & 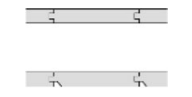 & Vertical & $\geq 100 \mathrm{~mm}$ & $\geq 150 \mathrm{~mm}$ \\
\hline & 돠 ㄴㄷ & & & \\
\hline \multirow[t]{3}{*}{$\begin{array}{l}\text { Force-fit paneling and } \\
\text { clad-ding }\end{array}$} & $t$ & Horizontal & $\geq 100 \mathrm{~mm}$ & $\geq 150 \mathrm{~mm}$ \\
\hline & $\sqrt{n}$ & Vertical & $\geq 150 \mathrm{~mm}$ & $\geq 200 \mathrm{~mm}$ \\
\hline & $\pi \quad 4 n$ & & & \\
\hline \multicolumn{5}{|l|}{ Open façades } \\
\hline $\begin{array}{l}\text { Open cladding } \\
\text { Strip cladding }\end{array}$ & $\begin{array}{lll}\square & \| & 4 \\
\square & n & 4 \\
\square & 4 & 4\end{array}$ & Horizontal & $\geq 200 \mathrm{~mm}$ & $\geq 250 \mathrm{~mm}$ \\
\hline $\begin{array}{l}\text { Cover cladding } \\
\text { Inverting cladding } \\
\text { Cover strip cladding }\end{array}$ & $\begin{array}{l}\bar{\square} \\
\bar{\square}\end{array}$ & Vertical & $\geq 250 \mathrm{~mm}$ & $\geq 250 \mathrm{~mm}$ \\
\hline & 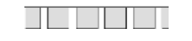 & & & \\
\hline
\end{tabular}

shrinkage are taken into account. The thickness of the cladding is an essential factor for the time at which continuing gaps in the façade cladding over its entire surface occur. It has already been shown in other studies that the increase in the thickness of the wooden cladding led to a temporary reduction in the heat release [17]. Considering the tests performed tests and the test results, claddings with a 
nominal thickness of $\geq 21 \mathrm{~mm}$ are recommended. Local reductions can be tolerated, but the thickness should not be less than $12 \mathrm{~mm}$. Furthermore, the wooden cladding should have a minimum density of $350 \mathrm{~kg} / \mathrm{m}^{3}$.

During the tests, it was also observed that vertically oriented cladding led to a faster and more severe vertical fire spread than a horizontally oriented cladding. This outcome can be ascribed to two causes in particular. On the one hand, the burning rate of wood in the direction of the grain can be assumed to be twice as high as that perpendicular to the grain [44] and, on the other hand, the additional substructure (crosswise lathing) in conjunction with the increased ventilated void cavity also contributes to a faster and a more intensive spread of fire. The reason for this is that cross-lathing is typically used for vertically arranged wooden cladding. This means that both vertical and horizontal battens are arranged underneath the cladding (as shown in Fig. 27 of the appendix), thus increasing the ventilation cavity to twice the size. The larger cavity and three-sided fire exposure on the vertically running lathing contributes to a faster spread of fire in the vertical direction and to a more severe exposure at horizontal fire stops.

Based on the tests performed, the ventilation cavity should be limited to a maximum depth of $50 \mathrm{~mm}$ (cross-lathing with max. $2 \times 25 \mathrm{~mm}$ ). In the case of cross lathing, the ventilation cavity should be closed at horizontal intervals of no more than $5 \mathrm{~m}$ by doubling up the vertical battening, as shown in Fig. 19 .

Furthermore, the ventilation cavity should be fully blocked (width $\geq 50 \mathrm{~mm}$ ) at the lateral ends of the façade and the internal corners, as shown in Fig. 20.

Another positive measure gained from the test regarded the reveal lining around the window opening and the diagonally fixed rain deflector above the window.

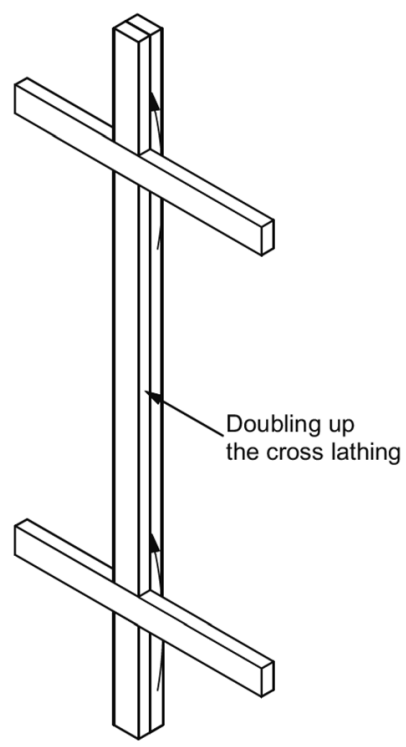

Figure 19. Representation of doubling up the cross lathing to avoid uncontrolled horizontal fire spread in the void cavity. 


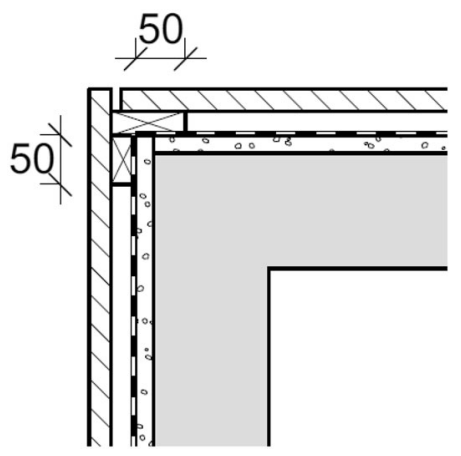

\section{Figure 20. Design principle for blocking the lateral ends of the façade.}

Both prevented a direct spread of fire into the ventilated void cavity, as shown in Fig. 28 of the appendix.

It should also be noted that, after the end of the test, the façade fires were able to be extinguished quickly and with little water. No special tactics or equipment was needed. This confirms the comparative studies on extinguishing techniques on wooden façades in [45].

\subsection{Fire Stops (No. 2)}

The investigations in Sect. 2.3 show that partially rear-ventilated façades perform better than fully rear-ventilated façades with respect to fire spread [11, 12]. This was also proven as part of the test series presented earlier. The blocking of the rear-ventilation cavity by timber battens is an effective means of slowing down the spread of fire along wooden façades. However, self-extinction or a reduction of the spread of fire across a story level cannot be achieved using this structural measure alone. Overhanging fire stops arranged at the floor level are more suitable with respect to the latter two requirements. As per the Swiss and Austrian guidance documents [13, 14], fire stops made of steel sheet, timber with sheet metal covering, and mineral-bonded boards are recommended as horizontal fire stops. In the current test series, the positive effect of horizontal steel sheets as fire stops was also confirmed over a longer test period. However, the effect of common wooden boards as horizontal fire stops (Test 3) could not be confirmed for a longer test period as part of this test series.

After a certain period, the wooden fire stops contributed to the spread of fire due to burning themselves and becoming charred through, but they also enlarged the horizontal affected area exposed by the flames, as shown in Fig. 14 in Test 3. Considering the tests performed, combustible fire stops, even those with sheet metal support, are not an effective means of preventing the spread of fire over a longer period of time.

Fire stops made of mineral-bonded boards were not explicitly investigated in the full-scale tests. However, challenges surrounding the adequate fixation of the fire stops were identified in model set-ups [32]. 
Composite fire stops made of steel sheets and mineral-based boards might offer advantages in terms of thermal expansion effects or fixation, but the behavior of such composite fire stops requires further investigation.

Effective fire stops should be made of steel sheets with a thickness $\geq 2 \mathrm{~mm}$. The fire stops must tightly fixed to the non-combustible substructure, as shown in Sect. 5.2, and the fasteners (screws $d \geq 5.0 \mathrm{~mm}$ ) should be anchored at least $35 \mathrm{~mm}$ into the load-bearing structure of the wall behind, as shown in Fig. 29 of the appendix.

As mentioned in Sect. 5.3, varying fire exposure may occur on the fire stops, depending on the type of façade cladding. The three relevant influencing factors are the design of the façade cladding, the design of the substructure, and the depth of the ventilation cavity. Based on the available information in the literature and the tests performed, the overhang depth $\times$ (as shown in Fig. 17 and provided in Table 6) are recommended. The objective was to prevent a spill by the flames of the relevant fire stop above the primary flame for a period of $>30 \mathrm{~min}$. Such behavior offers fire services in particular a chance to fight the façade fire after the executing their primary measures (e.g., occupant rescue). The most important effect on the horizontal fire stop is not the primary flame from the window opening itself, but rather the extensive burning of the façade cladding in the relevant story, as is obvious from Test 5. In principle, self-extinction can also be expected with these designs after the cladding below the relevant fire stop has charred completely. However, further tests which also take into account influencing factors like wind must be performed in order to confirm this point conclusively.

Interior corners have a noticeable influence on the flame height and the resulting temperatures in façade fires. This fact has already been demonstrated in a variety of studies [46]. These effects, which are particularly prominent for combustible wooden façades, must be considered when designing fire stops in interior corners. Based on the tests conducted and the information available from the literature, Table 6 also provides the overhang depth $\mathrm{x}$ (according to Fig. 17) for interior corners. The area of the increased overhang in interior corners should be at least $1.0 \mathrm{~m}$ to each side, as shown in Fig. 22.

During the observations for Test 5, it became obvious that fire spread across the horizontal fire stop may occur even though no direct exposure by flames exists, as shown in Figs. 16 and 26 of the appendix. This fact can be explained by three factors. On the one hand, the steel fire stops expanded under the thermal exposure, which consequently led to a joint opening in between the screwed spots of the fire stop, as shown in Fig. 21. The thermal exposure on the above structural timber elements (timber battens and cladding) increased through these gaps. Screw spacings of $300-400 \mathrm{~mm}$ were used In the five tests. Taking into account the temperature exposure according to Sect. 4 of about $800{ }^{\circ} \mathrm{C}$ and considering an expansion coefficient for steel of $11 \times 10^{-6} \mathrm{~K}^{-1}$ obtains an approximate thermal expansion in one dimension for a $400 \mathrm{~mm}$ spacing of $3.52 \mathrm{~mm}$ [47]. This thermal expansion would, approximately, lead to a gap of about $27 \mathrm{~mm}$ depth between the steel sheet and the outer wall face, which was confirmed by the test evaluation. Figure 21 shows the fire stop after the test, with reduced deformation but with a gap still present. In practice, fixation distances of $\leq 200 \mathrm{~mm}$ are recommended 


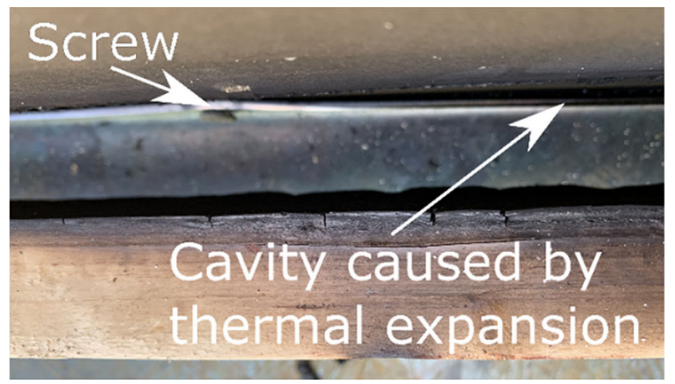

\section{Figure 21. View of the fire stop from above with gap caused by thermal expansion.}

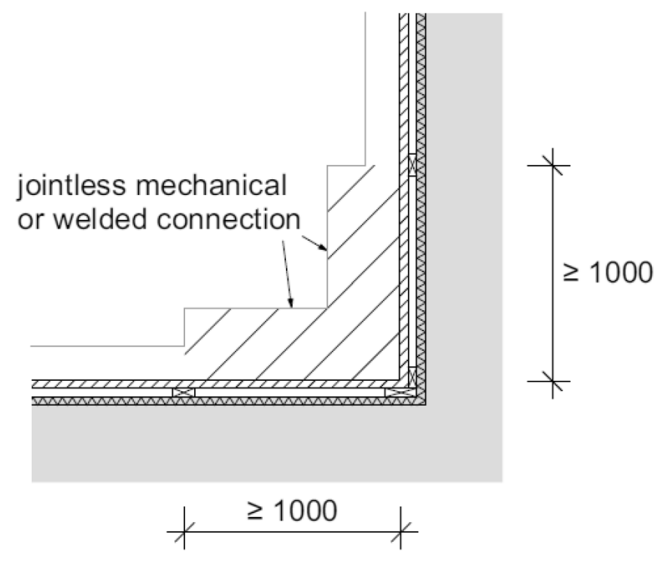

\section{Figure 22. Representation of the fire stops in the inner corner with} jointless mechanical or welded connection (hatching).

based on the test findings. In addition, in consideration of the effect of thermal expansion and weather resistance, the fire stops should have $20 \mathrm{~mm}$ slotted holes into which fasteners are inserted centrally. Furthermore, panel joints behind the fire stops should be avoided, filled, or calked.

The second factor regarding fire propagation across fire stops can also be attributed to the effect of thermal deformation and the upwards lifting of the steel sheet fire stops. During Test 5, it was observed that the fire stop, which was subjected to high fire exposure, lifted upward and moved closer to the timber lathing and the cladding above. The reduced distance and the high temperatures of the steel sheet fire stops caused a spread of fire to the wooden cladding and the timber lathing, as shown in Fig. 30 of the appendix. To counteract this effect, substructures and other combustible components should be arranged at a distance of $\mathrm{h} \geq 20 \mathrm{~mm}$ (Fig. 17) to the steel sheet fire stops. 
The third factor regarding fire spread without direct fire exposure at the fire stops can be the result of insufficient joint overlapping along the longitudinal direction of the fire stops and in the corners. Taking into account the thermal expansion, deflections and other deformations, the tests showed that a longitudinal overlap of $50 \mathrm{~mm}$ is not sufficient in all cases. For this reason, longitudinal joints in steel sheet fire stops should be joined mechanically or by welding in a friction-locked and jointless manner, or they should be designed with a joint overlap of at least $300 \mathrm{~mm}$. In the area of both sides of interior corners, the fire stops with a length of $\geq 1.0 \mathrm{~m}$ should have the aforementioned friction-locked jointless connections, as shown in Fig. 22.

\section{Conclusion and Outlook}

The aim of this study was to investigate fire stops on wooden façades when exposed to fire over a longer period of time and to evaluate their influence on the spread of fire.

During the research, fire stops made of steel sheet were identified as the most promising option for reducing the spread of fire. It also seems possible, taking into account various boundary conditions, that they can be used in the design of self-extinguishing wooden façades.

The decisive influencing factors for the dimensioning of the fire stops are:

- The type of the wooden façade cladding and substructure,

- The depth of the rear-ventilation void cavity, and

- The reaction to fire classification of the outer wall layer behind the wooden façade.

When designing fire stops for wooden façades, attention must be paid to the design of the fastening and the joint formation due to effects such as thermal expansion in addition to the dimensioning of interior corners.

By taking these parameters into consideration, fire-safe wooden façades can be designed regarding the respective fire safety requirements.

In the context of further investigations, other possible types of façade claddings should be considered in more detail and should consider a variety of effects, such as the fire of several floors below the relevant fire stop, as well as wind effects.

Within the scope of this study, only façade fires with a spread over one and a half stories were investigated. Further investigations are necessary in order to reach conclusions about the fire intensity of facade fires over several floors.

In addition, the topics of self-extinction, the fire stop interior corner design, and the investigation of the performance of composite boards made from steel and mineral materials represent other areas in need of further research.

The aesthetic appearance of a façade plays a decisive role in building design from an architectural point of view. Wide overhanging fire stops will usually be in conflict with architectural demands. For this reason, design options allowing architectural demands without reducing the safety level should be developed. In particular, the consequent further development of active and passive flame deflectors [48] could play a future role in this context. 


\section{Appendix}

See Table 7 and Figs. 23, 24, 25, 26, 27, 28, 29 and 30.

\section{Table 7}

Weather Data of the Individual Fire Tests

\begin{tabular}{lcll}
\hline Test & Temperature $\left[{ }^{\circ} \mathrm{C}\right]$ & Air pressure ${ }^{\mathrm{a}}[\mathrm{hPa}]$ & Weather \\
\hline 1 & 21.0 & 1023 & Sunny \\
2 & 27.3 & 1019 & Sunny \\
3 & 23.2 & 1021 & Slightly cloudy \\
4 & 20.6 & 1020 & Cloudy \\
5 & 20.1 & 1031 & Sunny \\
\hline
\end{tabular}

${ }^{\mathrm{a}}$ Taken from regular data of the German Weather Service

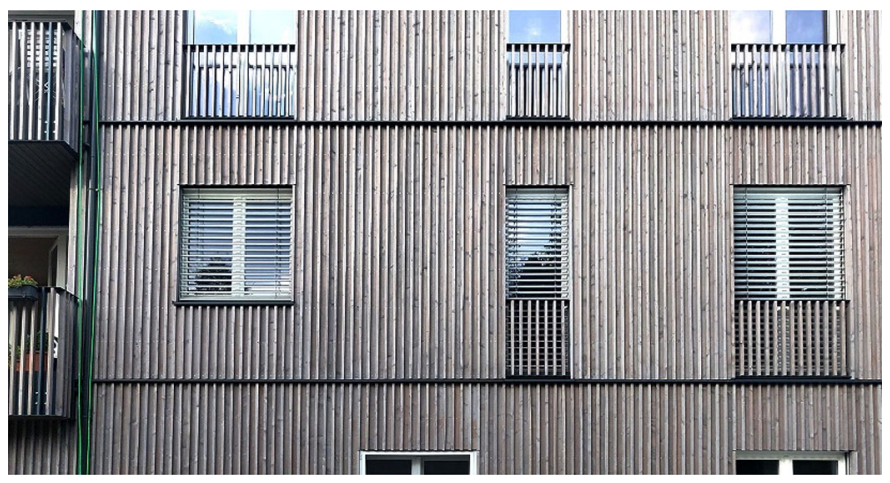

Figure 23. Façade as vertical cover strip cladding.

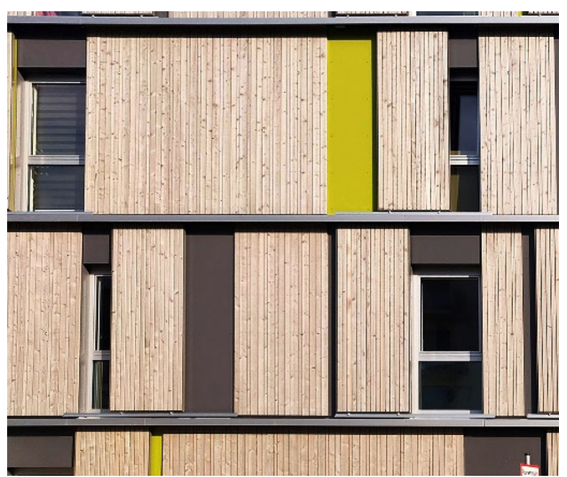

Figure 24. Façade as vertical tongue and groove cladding. 


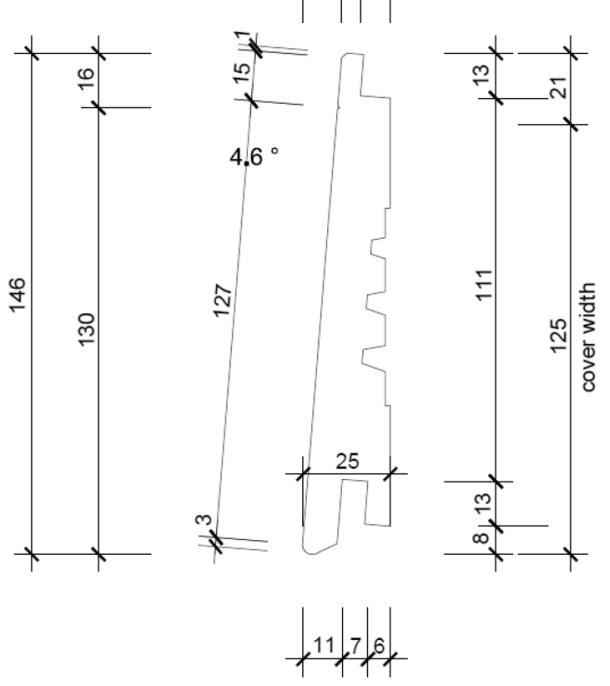

Figure 25. Dimensions of the wooden boards used for the tongue and groove cladding [in $\mathbf{m m}$ ].

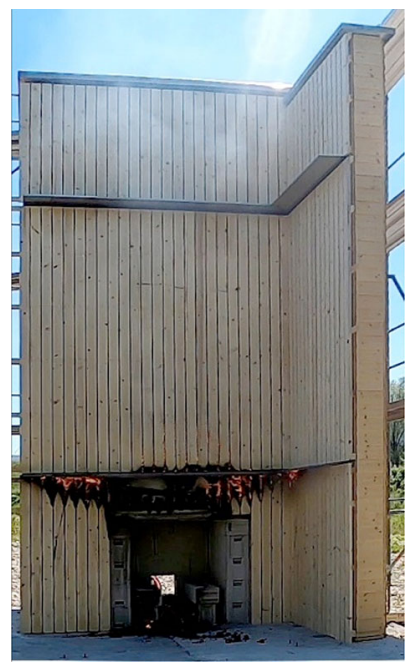

Figure 26. Photo of Test 5 at minute 28. 
(a)

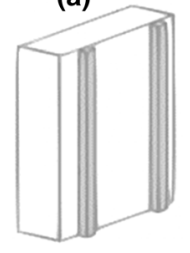

(b)

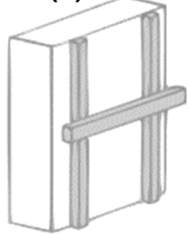

Figure 27. Substructure as a vertical or b cross-lathing.

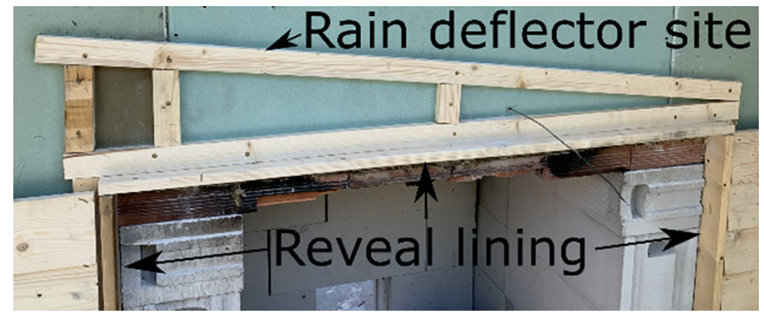

Figure 28. Reveal lining and rain deflector sife.

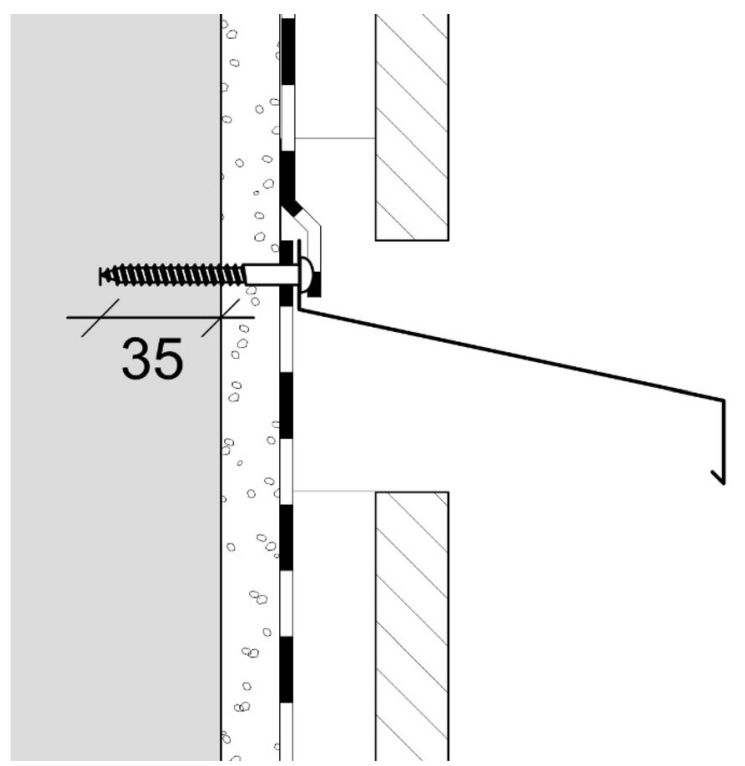

Figure 29. Anchorage depth of the screw for fixing the fire stops [in mm]. 


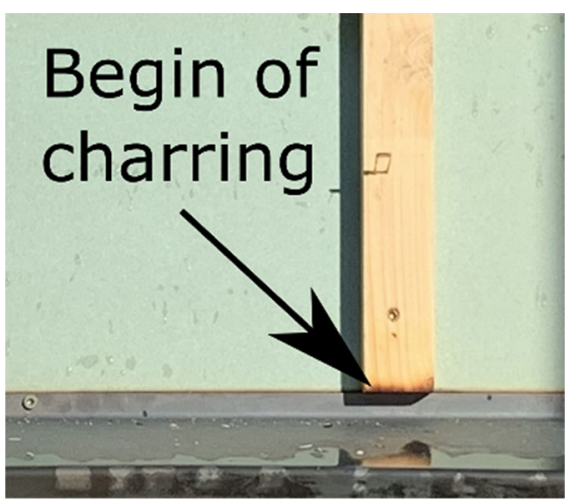

Figure 30. Onset of charring on the substructure in Test 2.

\section{SUPPLEMENTARY INFORMATION}

The online version contains supplementary material available at https://oi.org/ 10.1007/s10694-021-01174-2.

\section{Funding}

Open Access funding enabled and organized by Projekt DEAL.

\section{Open Access}

This article is licensed under a Creative Commons Attribution 4.0 International License, which permits use, sharing, adaptation, distribution and reproduction in any medium or format, as long as you give appropriate credit to the original author(s) and the source, provide a link to the Creative Commons licence, and indicate if changes were made. The images or other third party material in this article are included in the article's Creative Commons licence, unless indicated otherwise in a credit line to the material. If material is not included in the article's Creative Commons licence and your intended use is not permitted by statutory regulation or exceeds the permitted use, you will need to obtain permission directly from the copyright holder. To view a copy of this licence, visit http://creativecommons.org/licenses/by/4.0/.

\section{References}

1. United Nations Economic Commission for Europe; Green Building. https://unece.org/f orests/green-building. Accessed 28 June 2021 
2. Hildebrand J, Hagemann N, Thrän D (2017) The contribution of wood-based construction materials for leveraging a low carbon building sector in Europe. Sustain Cities Soc 34:405-418. https://doi.org/10.1016/j.scs.2017.06.013

3. Moore-Bick M (2019) Grenfell Tower inquiry: phase 1 report; report of the public inquiry into the fire at Grenfell Tower on 14 JUNE 2017, vol 4

4. Yeung J, Kwon J, Bae G (2020) Dozens hospitalized after fire engulfs 33-story apartment building in South Korea. CNN. https://edition.cnn.com/2020/10/09/asia/ulsan-kor ea-building-fire-intl-hnk/index.html. Accessed 30 Mar 2021

5. German Institute for Standardization (2012) DIN 68800-2:2012-02 Wood preservation-part 2: preventive constructional measures in buildings. Berlin

6. German Institute for Standardization (2010) DIN 18516-1:2010-06 Cladding for external walls, ventilated at rear-part 1: requirements, principles of testing. Berlin

7. Mayer E, Künzel H (1984) Notwendige Hinterlüftung an Außenwandbekleidungen aus großformatigen Bauteilen. IBP-Mitteilung 11 (1984). Nr. 92. Fraunhofer-Institut für Bauphysik

8. Kolaitis D, Asimakopoulou E, Founti M (2016) A full-scale fire test to investigate the fire behaviour of the "Ventilated Façade" system. In: Conference: Interflam 2016

9. Boström L, Skarin C, Duny M, McNamee R (2016) Fire test of ventilated and unventilated wooden façades (SP Rapport)

10. Colwell S, Baker T (2013) Fire performance of external thermal insulation for walls of Multistorey buildings. BRE Trust. 3rd edn

11. Hietaniemi J, Hakkarainen T, Huhta J, Jumppanen U-M, Kouhia I, Vaari J, Weckman H (2003) Ontelotilojen paloturvallisuus. Ontelopalojen leviämisen katkaiseminen. Tiedotteita, Espoo

12. Korhonen T, Hietaniemi J (2005) Fire safety of wooden façades in residential suburb multi-storey buildings. Espoo 2005. Technical Research Centre of Finland. VTT Working Papers 32

13. Bart B, Kotthoff I, Wiederkehr R et al (2019) Lignum-Dokumentation Brandschutz 7.1 Aussenwände - Konstruktion und Bekleidungen. Lignum, Holzwirtschaft Schweiz, Zürich

14. Austrian Standards Institute (2015) ÖNORM B 2332:2015 Fire resistant execution of façades of timber and of wood-based panels for building classes 4 and 5-Requirements and examples for execution. Wien

15. Hakkarainen T, Oksanen T, Mikkola E (1997) Fire behaviour of façades in multi-storey woodframed houses. Espoo 1997, Technical Research Centre of Finland, VTT Tiedotteita - Meddelanden Research Notes 1823

16. Teibinger M, Matzinger I, Schober P (2013) Experimental study of the fire performance of wooden façades. In: MATEC web of conferences volume 9; 1st international seminar for fire safety of façades, Paris. https://doi.org/10.1051/matecconf/20130902004

17. Dhima D, Gaillard JM (2017) Experimental study of the fire behaviour of wooden façades. Fire Sci Technol 2015:193-203. https://doi.org/10.1007/978-981-10-0376-9_19

18. Hameury S, Koutaiba E M, Anest-Bavoux P, Jullien Q, Lardet P, Georges V, Pinoteau N, Dhima D (2018) Fire safety of façades in medium and high-rise wood building. In: The French experience, 2018 world conference on timber engineering, Seoul

19. CSTB (2020) Bois construction et propagation du feu par les façades; Appréciation de laboratoire; 25/11/2020 - Version 3.0; CSTB \& Institut Technologique FCBA

20. Dhima D, Hameury S (2017) Fire behaviour of wooden façades - state of the art in France. In: FAÇADES WORKSHOP fire safe use of bio-based building products for façades - challenges and limitations, detailing and testing, Barcelona 
21. Martin Y, Eeckhout S, Lassoie L, Winnepenninckx E, Deschoolmeester B (2017) Fire safety of multi-storey building façades. BBRI, Brussels

22. Jullien Q, Koutaiba E M, Bavoux P A, Pinoteau N (2019) Horizontal deflectors impact on vertical wooden façade combustion. In: FSF 2019-3rd international symposium on fire safety of façades, Paris

23. Oleszkiewicz I (1990) Fire exposure to exterior walls and flame spread on combustible cladding. Fire Technol 26:357-375. https://doi.org/10.1007/BF01293079

24. Kordina K, Jeschar R, Bechtold R, Ehlert K-P, Wesche J (1978) Brandversuche Lehrte; Schriftenreihe "Bau- und Wohnforschung" des Bundesministers für Raumordnung, Bauwesen und Städtebau; Nr. 04.037, 1978, Bonn-Bad Godesberg

25. Fachkommission Bauaufsicht Projektgruppe MHHR (2002) Muster-Richtlinie über den Bau und Betrieb von Hochhäusern. Fassung April 2008 zuletzt geändert durch Beschluss der Fachkommission Bauaufsicht vom Februar 2012

26. Regierungskonferenz für die Koordination des Feuerwehrwesens (RKKF) (1999) Feuerwehr 2000 plus, Konzeption; Herlsau

27. Austrian Standards Institute (2013) ÖNORM B 3800-5:2013 Fire behaviour of building materials and components - part 5: fire behaviour of façades - requirements, tests and evaluations. Wien

28. Engel T, Werther N (2020) Analyse der zulässigen Brandausbreitung über die Fassade. Bautechnik 97:558-565. https://doi.org/10.1002/bate.202000007

29. Kotthoff I (2000) Forschungsbericht BI5-8001 96-18: Erarbeitung realer Prüfbedingungen für die Durchführung von Original-Brandprüfungen an B 1-Fassadensystemen und eines Verfahrens zur Berechnung von Brandabläufen an Fassaden. Materialforschung und Prüfungsanstalt für das Bauwesen Leipzig e.V. 1. Ausfertigung, 3. Okt. 2000

30. Abecassis Empis C (2010) Analysis of the compartment fire parameters influencing the heat flux incident on the structural façade. Dissertation, Edinburgh

31. German Institute for Standardization (2017) DIN 4102-20:2017-10 Fire behaviour of building materials and building components - part 20: complementary verification for the assessment of the fire behaviour of external wall claddings. Berlin

32. Grimm W (2020) Fire performance of wooden façades (Holzfassaden aus brandschutztechnischer Sicht). Master Thesis, Technical University of Munich

33. Ren F, Zhang X, Hu L, Sun X (2019) An experimental study on the effect of fire growth in a lower-floor compartment on fire evolution and facade flame ejection from an upper-floor compartment. Proc Comb Inst 37:3909-3917. https://doi.org/10.1016/ j.proci.2018.07.014

34. Bechtold R (1977) Zur thermischen Beanspruchung von Außenstützen im Brandfall. Institut für Baustoffkunde und Stahlbetonbau der Technischen Universität Braunschweig. Dissertation, Technische Universität Braunschweig

35. European Committee for Electrotechnical Standardization (2013) EN 60584-1 Thermocouples - part 1: EMF specifications and tolerances (IEC 60584-1:2013). Brussels

36. Grimm W, Engel T (2020) Versuchsbericht; Brandversuche an Holzfassaden - Versuch 1; Horizontale Nut und Feder-Schalung mit Reduzierung der Hinterlüftung. Technical University of Munich

37. Grimm W, Engel T (2020) Versuchsbericht; Brandversuche an Holzfassaden - Versuch 2; Horizontale Stülpschalung mit Stahlblechschürze (100 mm). Technical University of Munich

38. Grimm W, Engel T (2020) Versuchsbericht; Brandversuche an Holzfassaden - Versuch 3; Vertikale Nut und Feder-Schalung mit Holzschürze (40 mm). Technical University of Munich 
39. Grimm W, Engel T (2020) Versuchsbericht; Brandversuche an Holzfassaden - Versuch 4; Vertikale Nut und Feder-Schalung mit Unterbrechung der Hinterlüftung. Technical University of Munich

40. Grimm W, Engel T (2020) Versuchsbericht; Brandversuche an Holzfassaden - Versuch 5; Vertikale Offene Schalung mit Stahlblechschürze $(250 \mathrm{~mm})$. Technical University of Munich

41. Grimm W, Engel T (2020) Versuchsbericht; Brandversuche an Holzfassaden - Versuch 6; Holztafelbauwand mit horizontaler Nut und Feder-Schalung. Technical University of Munich

42. Engel T, Brunkhorst S, Steeger F, Winter S, Zehfuß J, Kampmeier B, Werther N (2020) TIMpuls Grundlagenforschung zum Brandschutz im Holzbau - Abbrandraten, Schutzzeiten von Bekleidungen und Nachbrandverhalten von Holz. Bautechnik 97:97107. https://doi.org/10.1002/bate. 202000043

43. Jiang L, Zhao Z, Tang W, Miller C, Gollner M (2018) Flame spread and burning rates through vertical arrays of wooden dowels. Proc Combust Inst . https://doi.org/10.1016/ j.proci.2018.09.008

44. White R H, Dietenberg M A (2010) Fire safety of wood constructions. Wood handbook-Wood as an engineering material, Chapter 18, General Technical Report FPLGTR-190 Madison WI

45. Hox K, Bøe A S (2017) Slokkemetoder med lite vann, SP Fire Research, Trondheim, Norway, A17 20099-01:1, 2107

46. McGrattan K, Stroup D (2020) Wall and corner effects on fire plumes as a function of offset distance. Fire Technol 57:977-985. https://doi.org/10.1007/s10694-020-01053-2

47. Serway R, Jewett JW (2014) Physics for scientists and engineers with modern physics, 9th edn. Cengage Learning Brooks/Cole, Boston

48. Harmathy T Z (1974) Flame deflectors. Building Research Note, 1974-10. Fire Research Section Division of Building Research, NRC. Ottawa

Publisher's Note Springer Nature remains neutral with regard to jurisdictional claims in published maps and institutional affiliations. 